\title{
FOOD LOSS AND WASTE IN INDIA: THE KNOWNS AND THE UNKNOWNS
}

\section{EXECUTIVE SUMMARY}

\section{Highlights}

- Research on food loss and waste in India is in the early stages, and is mainly focused on the quantity of post-harvest loss.

- Data on food waste at the retail, household and service level is limited to a few perception studies. Data on food waste at household level is almost nonexistent.

- India has not yet begun reporting on Sustainable Development Goal 12.3, despite having undertaken national-level surveys on post-harvest loss.

- The existing data on losses are not comparable due to differences in measurement metrics. Hotspots and critical loss points in food supply chains need to be identified using a standardized approach.

- The social, economic, and environmental aspects of food loss and waste are largely unexplored in the studies reviewed in this paper. Gender-disaggregated research on food loss and waste is neither available nor considered in improving technology or other solutions for its management.

- A roadmap is needed for managing food loss and waste in India, based on data-driven strategies and solutions and taking into account the challenges faced by diverse stakeholders. Concerted efforts are needed to increase awareness of and research into all the dimensions of food loss and waste.

- A new multi-stakeholder action coalition could foster collaboration and partnerships, prioritize the research agenda, mobilize action, and support policy and its implementation for sustainable food systems.

\section{CONTENTS}

Executive Summary ..... 1

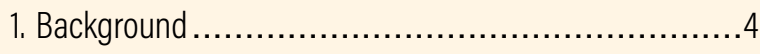

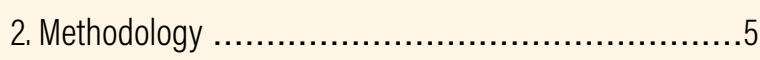

3. Synopsis of the Literature Review ..................... 7

4. Food Loss in India ................................. 9

5. Food Waste in India ................................... 17

6. Social, Economic, and Environmental Impacts ..........19

7. Conclusions and the Way Forward ..................... 20

Appendix A .......................................21

Appendix $B$............................................. 21

Appendix C ........................................... 22

Appendix D .......................................... 24

Appendix E ........................................ 26

List of Abbreviations ................................... 29

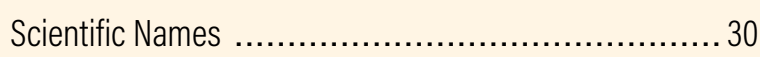

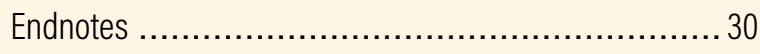

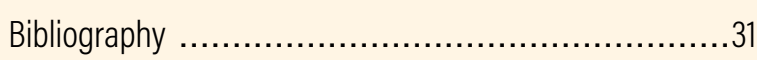

Working Papers contain preliminary research, analysis, findings, and recommendations. They are circulated to stimulate timely discussion and critical feedback and to influence ongoing debate on emerging issues. Most working papers are eventually published in another form and their content may be revised.

Suggested Citation: Agarwal, M., S. Agarwal, S. Ahmad, R. Singh, and K.M. Jayahari. 2021. "Food Loss and Waste in India: The Knowns and the Unknowns”. Working Paper. Mumbai: World Resources Institute India. Available online at http:// www.wri.org/publication/food-loss-and-waste-in-india. 


\section{Introduction}

Despite high levels of food production, India ranks only $94^{\text {th }}$ out of 107 countries on the 2020 Global Hunger Index. The estimated economic value of post-harvest losses in India was INR 926.51 billion (USD 15.19 billion) in 2014 (Jha et al. 2015). ${ }^{1}$ This was 0.6 percent of the country's GDP and two-and-a-half times higher than the budget of the Ministry of Agriculture and Farmers Welfare (MoAFW) in fiscal year (FY) 2014 (FY2014). The COVID-19 pandemic is exacerbating nutrition insecurity in India (Singh 2020). In a world where hunger and malnourishment are on the increase, unacceptable levels of food loss and waste call for urgent action.

\section{Reducing food loss and waste is recognized} globally as an opportunity to address food and nutrition insecurity and reduce greenhouse gas (GHG) emissions while also advancing economic development. The recent EAT-Lancet Commissions' report (EAT 2019) identifies large reductions in food loss and waste as a crucial dimension of sustainable food systems in order to achieve healthy diets for 10 billion people by 2050. The significance of reducing food loss and waste for improving social, economic, and environment outcomes is also recognized in Target 12.3 of the Sustainable Development Goals (SDGs), which calls for reducing food loss and halving food waste by 2030. Target 12.3 also contributes to the achievement of the other SDGs by increasing food availability, enhancing farmers' incomes, easing pressure on land and water resources, and reducing GHGs. In recognition of its importance, significant strategies have been developed to minimize food loss and waste at the global level. It is estimated that 50 percent of the world's population now lives in countries that have set an explicit, public target aligned with SDG 12.3 (Flanagan et al. 2019). However, despite having national-level surveys on post-harvest losses, India has not yet set such a target (NITI Aayog 2019).

\section{About This Working Paper}

This paper summarizes the state of play on food loss and waste research in India. This study was undertaken by the World Resources Institute India (WRI India) and the Food and Land Use (FOLU) Coalition's India platform to understand the magnitude of, and identify the hotspots and critical loss points of, food loss and waste in India; identify the strategies and interventions implemented to date; highlight the gaps in research, policy, and practice; and suggest some next steps.
The paper presents the results of a systematic analysis of 106 peer-reviewed and gray literature publications, as well as consultations with sectoral experts. It explores food loss and food waste separately, as each requires targeted strategies. For each it looks at the existing research, key drivers and solutions, and current government interventions, and identifies the gaps that need to be filled. It also summarizes the current evidence for the social, economic, and ecological impact of food loss and waste. The paper concludes with recommendations on the way forward for efficient food loss and waste management in India.

\section{Key Findings}

National and subnational estimates of food loss and waste are fragmented and not comparable

\section{Our findings reflect a growing emphasis on} and concern about food loss and waste. The vast majority of studies reviewed (87) were from the past decade (Figure ES-1).

There is much more research emphasis on postharvest losses than on food waste in India. Even in post-harvest losses, the quality (nutrition) aspects of food loss remain neglected. Whereas 72 studies were on food loss, only 22 were on food waste; 12 covered both loss and waste (Figure ES-2).

Empirical research on food waste is very scarce. Most studies were based on the perceptions of restaurant/hotel owners and consumers, and relied largely on the behavioral approach toward food waste. Though there are national estimates of food losses, there are no national or subnational estimates of food waste. Most of the publications analyzed relied on secondary data (72 studies). Only 22 studies on food loss and 11 on food waste included primary data (Figure ES-3).

The evidence is patchy. Fruits and vegetables (33) followed by cereals (24) account for the biggest share of the commodities reviewed (Figure ES-4). Research is concentrated in only a few states-Karnataka, Andhra Pradesh, Maharashtra, and Punjab-likely reflecting the fact that the crop selected in the reviewed studies is the dominant crop grown in these states in terms of production quantity.

The lack of a standard metric for measuring food loss and waste means that existing estimates are not comparable. This makes it impossible to present consistent information on hotspots or critical loss points and to build systematic evidence 
for prioritizing action and resource allocation for decision-makers.

Without a standard and systematic research approach, it is difficult to build systematic evidence for prioritizing action

The causes outlined in the literature are disparate and not based on systematic analysis of data. The three main drivers of food losses identified in the reviewed studies were related to poor storage facilities (including pest management), poor transportation at different stages of the food supply chain, and harvesting techniques.

Most studies do not use data in analyzing solutions for post-harvest losses. Several studies emphasize the management of post-harvest losses by improving farm operations, such as mechanization of harvesting and threshing, improving storage facilities, establishing cold chains, improving access to markets, and so on. However, the costs and benefits of the existing interventions are largely unexplored and overlook the impact on smallholder farmers, women, and other vulnerable groups.

There is no attempt to consider gender dimensions in improving technology or other solutions to manage food losses. This is despite the fact that post-harvest operations such as winnowing, drying, and storage are primarily the responsibility of women.

Figure ES-1 | Number of Publications by Year of Publication

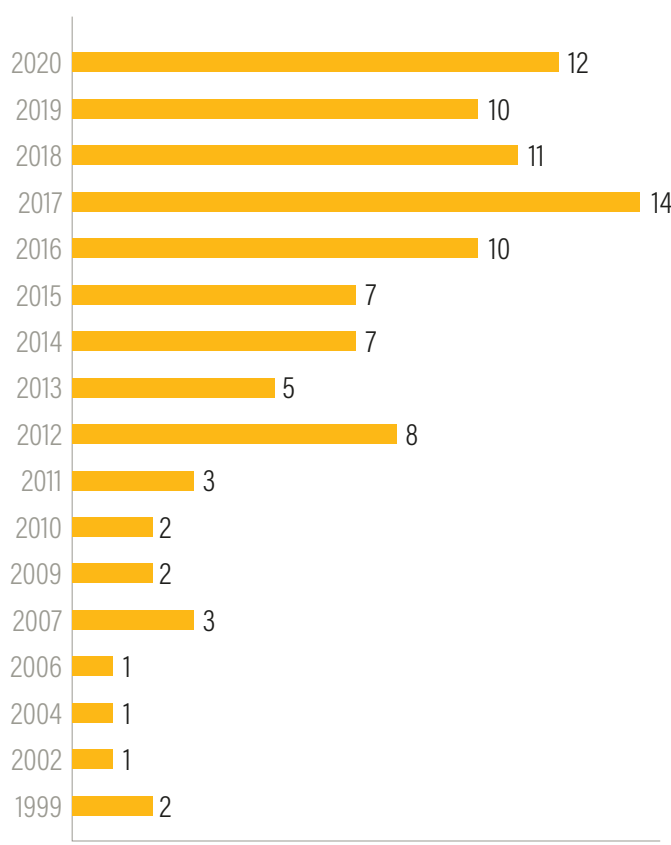

Note: As many as 87 studies reviewed were from the last decade, reflecting a growing emphasis on food loss and waste.

Source: WRI India analysis.
Figure ES-2 | Number of Publications by Theme

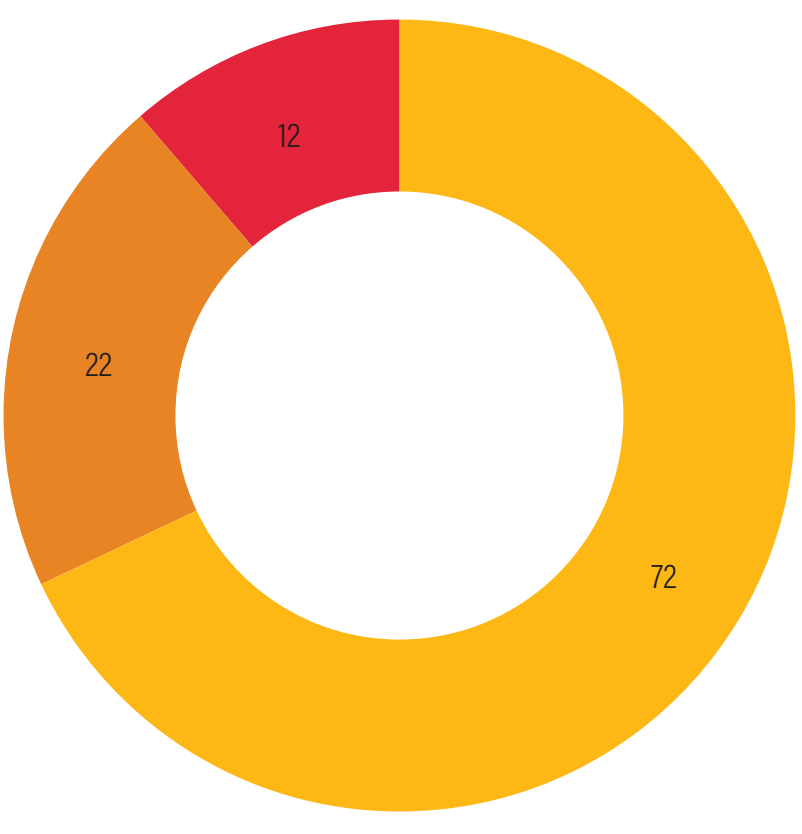

Food loss — Food waste $\quad$ Food loss and waste

Note: Most publications were on food loss, with 22 on food waste and 12 on both food loss and waste.

Source: WRI India analysis.

Figure ES-3 | Number of Publications by Type of Data Source

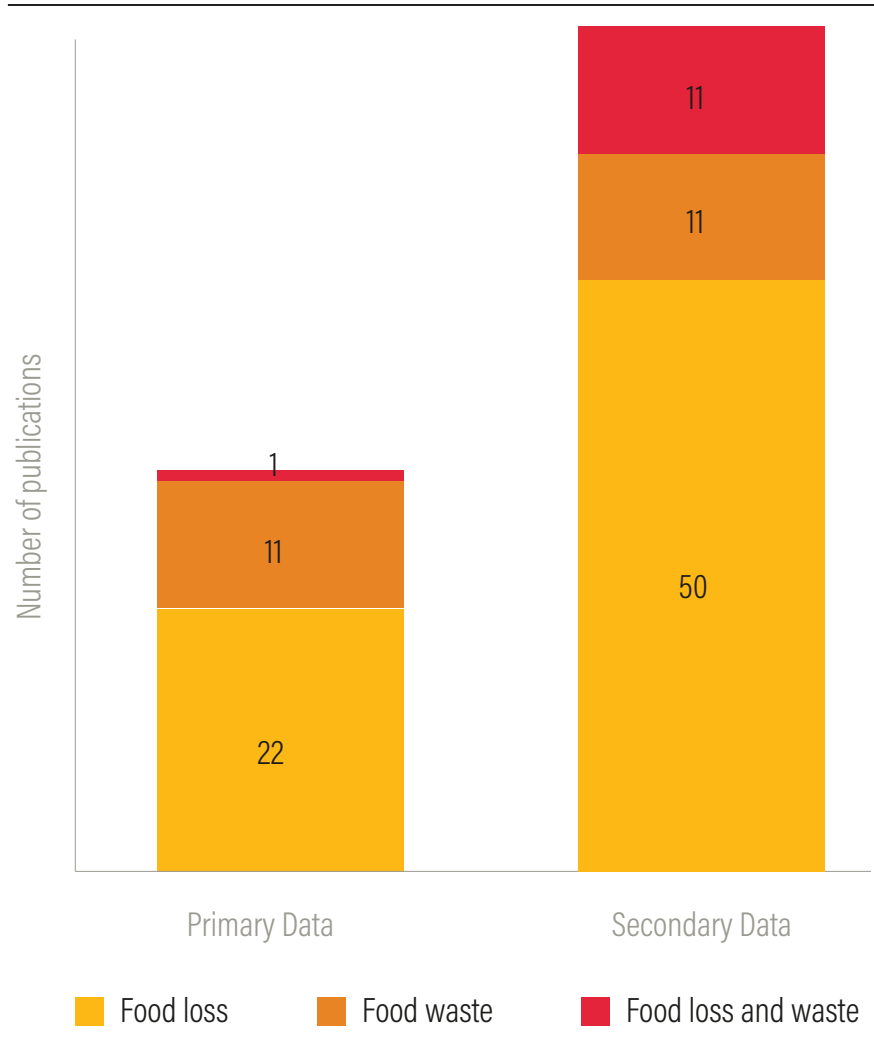

Note: As many as 72 publications relied on secondary data; only 22 publications on food loss and 11 for food waste, respectively, used primary data (mainly behavioral studies). Source: WRI India analysis. 
Figure ES-4 | Number of Publications by Type of Data Source

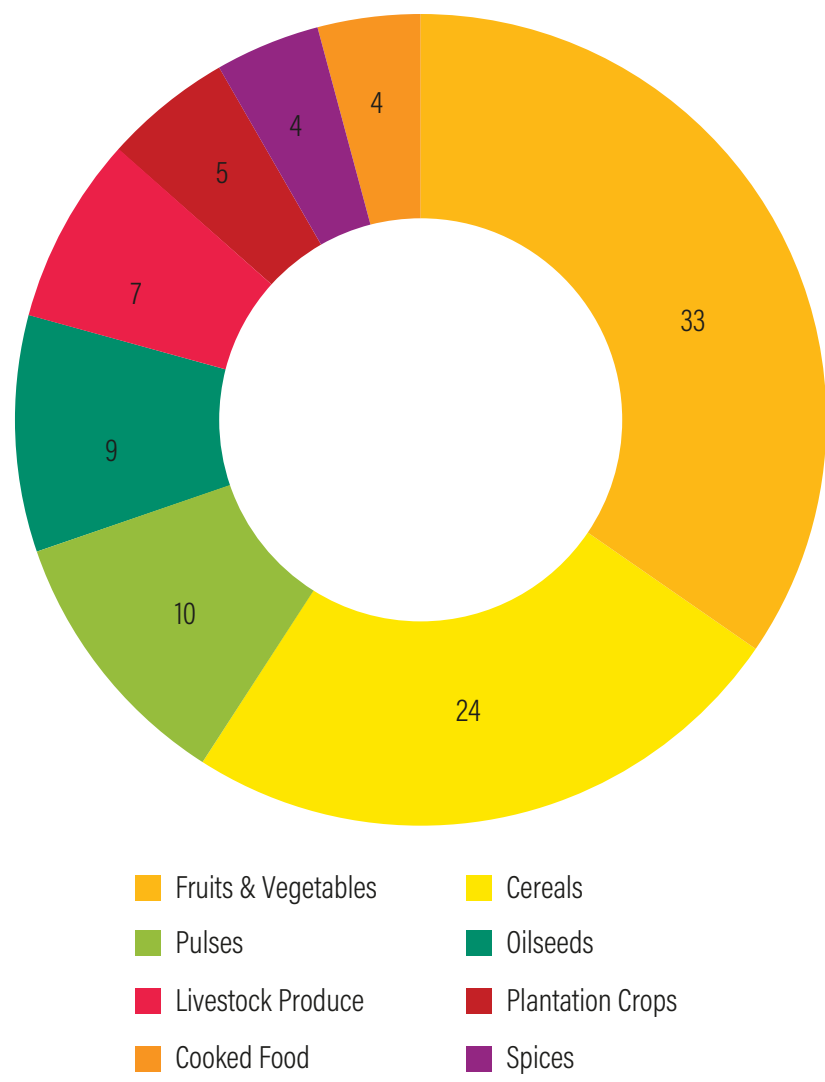

Note: Cereals, fruits, and vegetables account for the largest share of publications Source: WRI India analysis.

\section{There is very limited policy analysis of the} strategies and interventions to manage food loss and waste in the reviewed papers. The literature review does not provide much insight into India's status on SDG target 12.3; despite being one of the few nations to have undertaken national-level surveys of food losses, India has not yet begun reporting on SDG 12.3.

As food supply chains cut across state boundaries, this demands overall intervention by the Union Government of India. Agri-logistics and post-harvest management in India are not the responsibility of any one dedicated ministry or government department. This, combined with lack of data, can result in fragmented approaches.

\section{The Way Forward}

The significant gaps in research, policy, and practice need to be addressed systematically to manage food loss and waste in India. We outline some practical recommendations for moving forward:
Adopt standards for measuring and accounting. Adopting a standard metric for estimating food loss and waste will help generate comparable data from different studies across time and geographies and hence will be more useful for decision-makers, the private sector, and civil society. The global Food Loss and Waste Accounting and Reporting Standard (or the Food Loss and Waste [FLW] Standard) developed by the FLW Protocol could be adopted in India (https://www.flwprotocol.org/). It will need to be adapted to the Indian context.

Put the issue of food loss and waste on the research agenda at all levels in India. The research agenda needs to include estimation of food waste nationally, as well as the social, economic, and environmental impact of food loss and waste.

Create awareness and mobilize a movement for reducing food loss and waste in India that embraces diverse stakeholders.

Set up a multi-stakeholder action coalition to

foster collaboration and partnerships to manage food loss and waste,

prioritize the research agenda on food loss and waste in India,

develop strategies and mobilize action, and

support policy development and implementation for sustainable food and land-use systems.

It is vital that reducing food loss and waste becomes a priority action area for public and private institutions in India. Going forward, fostering multi-stakeholder partnerships can help put food loss and waste at the top of the agenda and develop strategies to manage food loss and waste in India.

\section{BACKGROUND}

Post-harvest losses in India were estimated to be INR 926.51 billion (USD 15.19 billion) in FY2014, representing a significant loss of national wealth (Jha et al. 2015). At the same time, India ranks only 94th out of 107 countries on the 2020 Global Hunger Index (Grebmer et al. 2020). The COVID-19 pandemic is underlining the fact that food insecurity remains the biggest hurdle in India, and threatens to become even bigger amid the current health and economic crisis (Singh 2020). India is one of the leading food producers in the world, and so its land, water, and carbon footprint of food loss and waste is also expected to be very high. 
Globally, food loss and waste (defined in Box 1) is recognized as a serious threat to food security, the economy, and the environment. Target 12.3 of the 2015 Sustainable Development Goals (SDGs) calls for reducing food loss and halving food waste by 2030 . Reducing food loss and waste can significantly contribute to the other SDGs by increasing the availability of food, enhancing farmers' incomes, easing pressure on land and water resources, and reducing greenhouse gas (GHG) emissions. Globally there have been several initiatives to address food loss and waste. ${ }^{2} \mathrm{~A}$ recent report launched by the World Resources Institute (WRI) aims to set a global action agenda to accelerate reduction of food loss and waste. It identifies a three-pronged approach: set a reduction target aligned with SDG 12.3; measure food loss and waste, monitoring progress over time; and ensure action by all actors in the food supply chain (Flanagan et al. 2019).

India has not yet set a target aligned with SDG 12.3 and has not yet begun reporting on it. India is one of the few countries to have conducted two national surveys, led by the Indian Council of Agricultural Research (ICAR) as well as several subnational studies and case studies carried out by universities, local research institutions, nongovernmental organizations, and international organizations to estimate the postharvest losses of selected crops in selected supply chain stages. However, no such studies have been conducted on measuring food waste. Several government schemes and policies are focused on strengthening post-harvest management, but the challenge of reducing food loss and waste requires action by numerous actors in the food supply chain, from producer to consumer, in order to implement context-specific interventions.

In order to make progress toward reducing food loss and waste in India, it is vital to understand the existing knowledge, practice, and policy on the issue. With this objective, the authors conducted a systematic review of the literature on food loss and waste in India to provide insights into its extent (how much, where, and why); the social, economic, and ecological impacts; and available solutions. The study addresses the following questions:

What is the state of knowledge regarding the magnitude, hotspots, and critical loss points of food loss and waste in India?

- What have been the recommended strategies and practical solutions to manage food loss and waste in India?

- What gaps in research, policy, and practice need to be closed to manage food loss and waste in India?
Box 1 | Food Loss and Waste Terminology

Food refers to any substance, whether processed, semiprocessed or raw, intended for human consumption.

The food supply chain consists of the following segments: agricultural production and harvest, slaughter, or catch; post-harvest, slaughter, and catch operations; storage; transportation; processing; wholesale and retail; and consumption by households and food services.

Food loss is the decrease in the quantity or quality of food resulting from decisions and actions by food suppliers in the segments of the chain excluding retail, food service providers, and consumers. Also known as post-harvest losses.

Food waste is the decrease in the quantity or quality of food resulting from decisions and actions by retailers, food services, and consumers.

Quantitative food loss and waste is the amount or mass of food destined for human consumption removed from the food supply chain.

Qualitative food loss and waste is the decrease in food attributes that reduces its value in terms of intended use. It can result in reduced nutritional value (e.g., smaller amounts of vitamin C in bruised fruits) and/or the economic value of food because of noncompliance with quality standards.

Source: Adapted from FAO (2019).

The next section details the methodology followed for the literature review. Section 3 summarizes the main findings from the literature review analysis. Sections 4 and 5 are devoted to food loss and food waste, respectively. Each section summarizes the available data, the key drivers and solutions, government interventions, and main research gaps. Section 6 explores the social, economic, and environmental dimensions of both food loss and waste. Section 7 concludes the paper and outlines the way forward for the efficient management of food loss and waste in India.

\section{METHODOLOGY}

The literature search was carried out using a variety of search strings in online databases (Google Scholar and Science Direct), and through a general search using Google's search engine to identify the gray literature. The keywords used for each dimension are listed in Figure 1. Based on these keywords, seven search strings were developed: four for food loss and three for food 
waste, using Boolean operators (AND, OR, and NOT) (Appendix A). Searches were conducted separately for food loss and food waste.
To shortlist the relevant publications, all the search results were screened at four levels (Figure 2 provides an overview of the publication selection process).

\section{Figure 1 | Keywords Used for the Search}

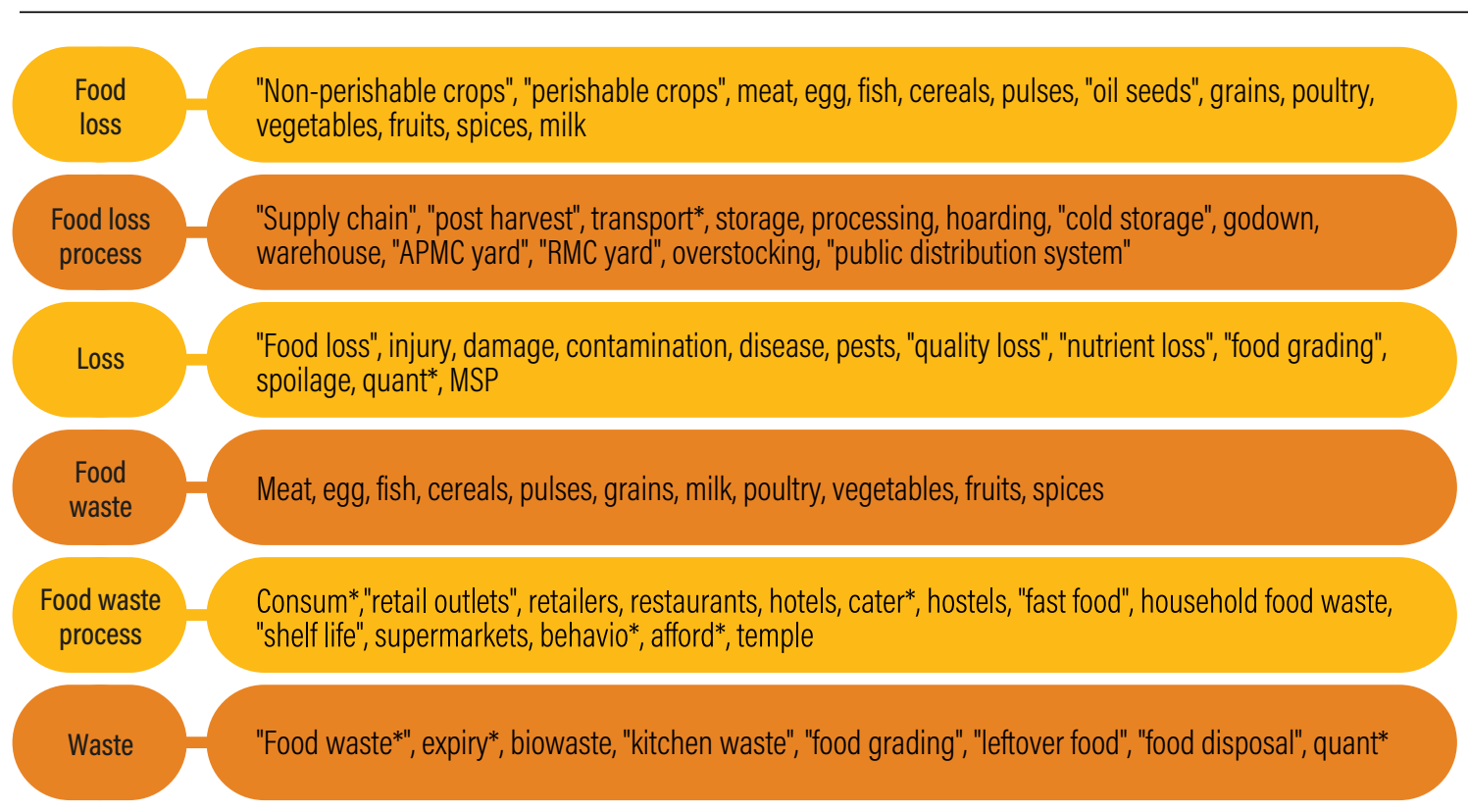

Note: APMC: Agricultural Produce Market Committee; RMC: Regulated Market Committee; MSP: Minimum Support Price. Source: WRI India authors.

Figure 2 | An Overview of the Process of Selecting Publications

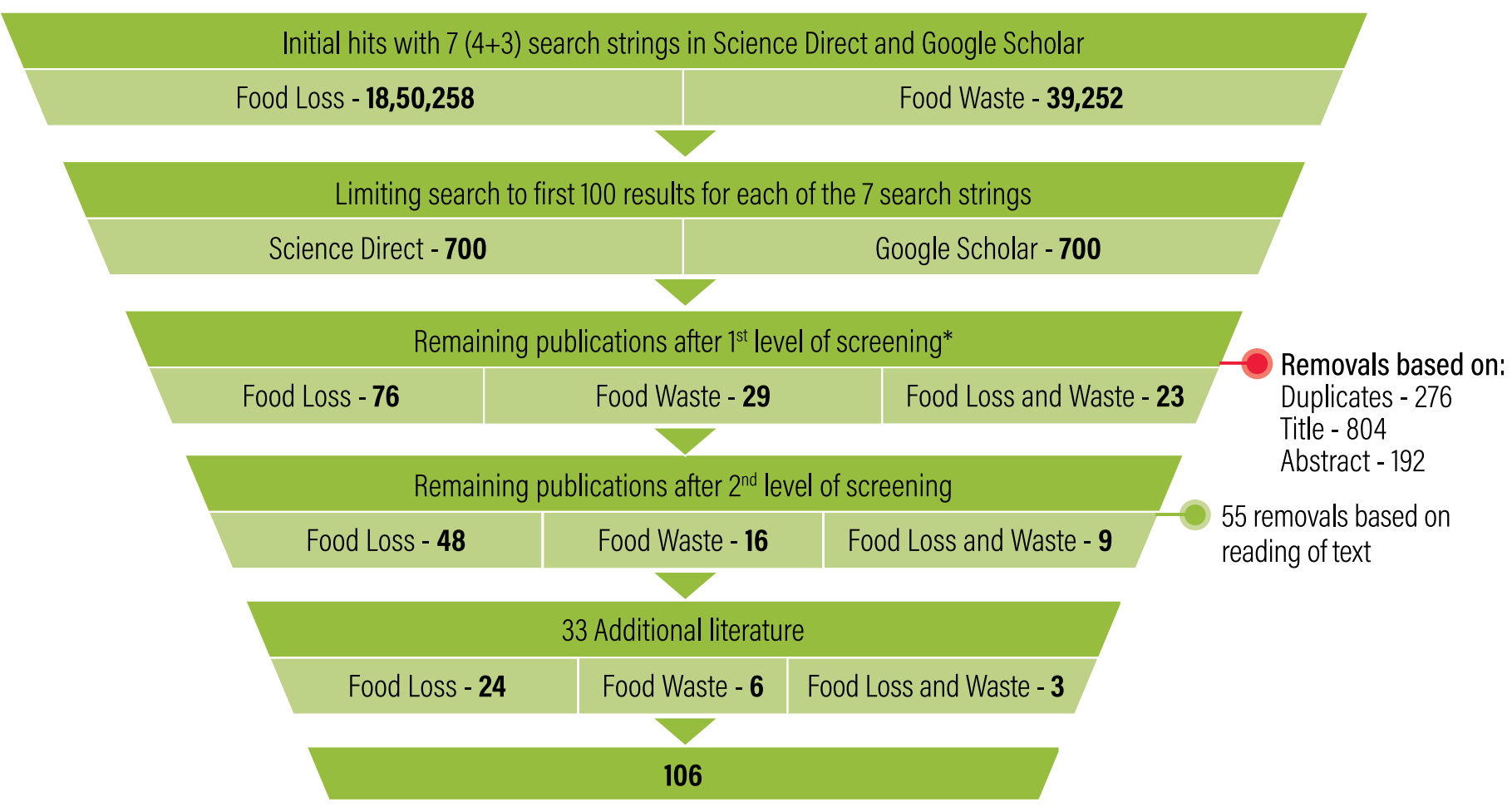

Note: *50 randomly selected papers subjected to Kappa analysis resulting in 0.58 for Food Loss and 0.56 for Food Waste papers 
First, all the duplicates were removed, following which the papers were screened by their titles based on inclusion and exclusion criteria (Figure 3). Notably, the shortlisting excluded publications on the use and disposal of food waste to keep the focus on reducing food loss and waste rather than on managing the waste emanating from discarded foods. The shortlisted publications were then screened from their abstracts. A kappa test for bias was conducted at this stage, with a satisfactory test result. The final screening was based on reading the entire paper: 161 publications were read, resulting in 106 publications being selected for review.

A technical working group was set up to provide guidance on the methodology and the key findings; and five interviews with sectoral experts were conducted to substantiate the findings and gaps (Appendix B). Additional online searches were conducted at the time of analysis and writing, such as for understanding conceptual frameworks on food loss and waste and for mapping relevant government schemes.
Figure 3 | Inclusion and Exclusion Criteria used to Shortlist Studies

\section{INCLUSIONS \\ EXLUSIONS}

- Global study with data/ information on India

- Social, economic, and environmental impact

- Causes of food loss and waste

- Interventions or management practices

- Pertaining to SDGs and impact on gender
- Global or any other study not related to food loss and waste in India

- Non-food crops

- Pre-harvest losses (standing crops)

- Food waste utilization, e.g. generating biofuel

- Disposing of food waste (waste management)
Source: WRI India authors

\section{SYNOPSIS OF THE LITERATURE REVIEW}

Over 106 studies were selected for the review: 49 are peer-reviewed research papers, and the remaining documents are government reports, technical reports, media articles, and blogs. Table 1 summarizes the key findings.

\section{Table 1 | Key Findings of the Literature Review}

\section{RESULTS}

87 studies were from the last decade (Figure 4).

\section{KEY MESSAGES AND IMPLICATIONS}

Greater focus on food loss and waste issues in the last decade.

Greater emphasis on post-harvest losses in India than on food waste. This is in line with the global perception that food losses make up a greater share than food waste in developing countries (FA0 2011).

loss and waste (Figure 5)

72 publications relied on existing (secondary) data for their studies. Only 22 studies on food loss and 11 on food waste used primary data (Figure 8).

Highlights the dearth of primary research in the sector. In particular, there is no national or subnational study on food waste.

The concentration of research efforts in a few states reflects the dominant crops grown there and the research objectives of local/ regional agricultural research institutes.

Limited focus on other commodities such as pulses, livestock produce, etc.

Reflects the dearth of "large-scale" studies covering multiple commodities and geographies.

Reflects a focus on food grains and perishables.
Of the 106 studies reviewed, 55 were not specific to any commodity; 34 studies were specific to a single commodity; only 2 studies covered all eight commodity types (Figure 7).
Mango (10), rice (11), and wheat (10) are the most studied commodities in the majority of studies reviewed. 
Figure 4 | Number of Publications by Year of Publication

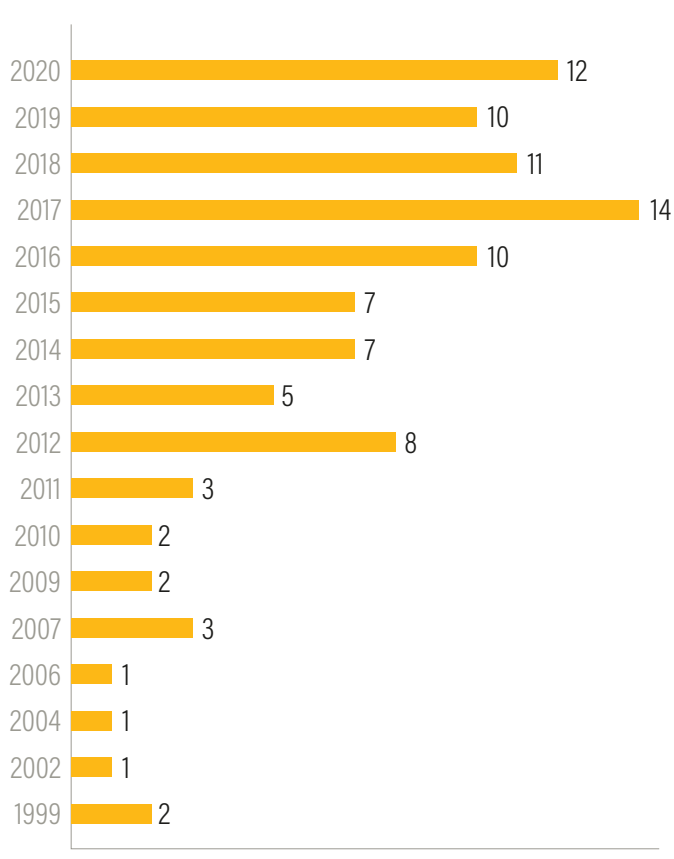

Note: As many as 87 studies reviewed were from the last decade, reflecting a growing emphasis on food loss and waste.

Source: WRI India analysis.

\section{Figure 5 | Number of Publications by Theme}
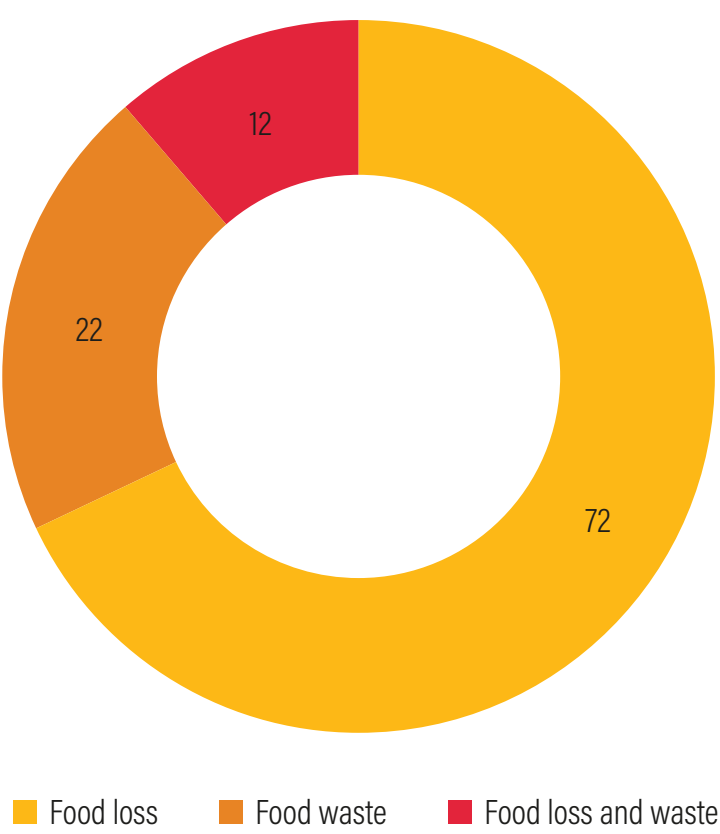

Note: Most publications were on food loss, with 22 on food waste and 12 on both food loss and waste.

Source: WRI India analysis.
Figure 6 | Number of Publications by Commodity Focus

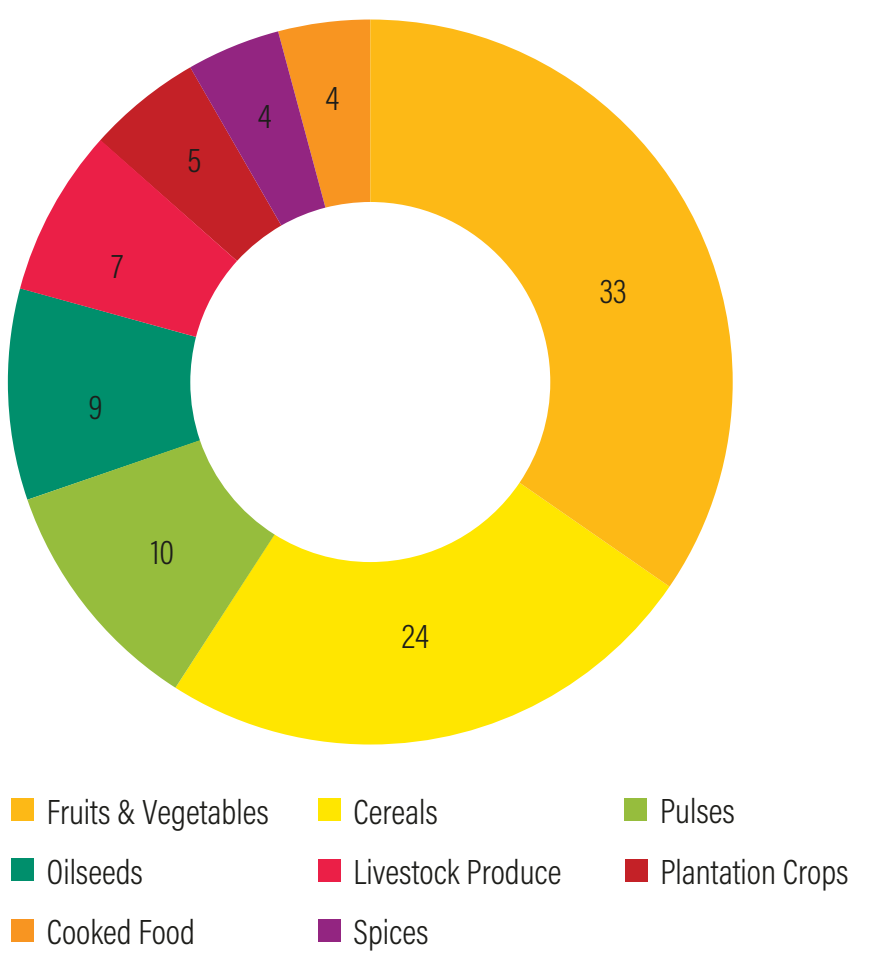

Note: Cereals, fruit, and vegetables account for the largest share of publications. Source: WRI India analysis.

Figure 7 | Number of Publications by Multiple Commodity Focus

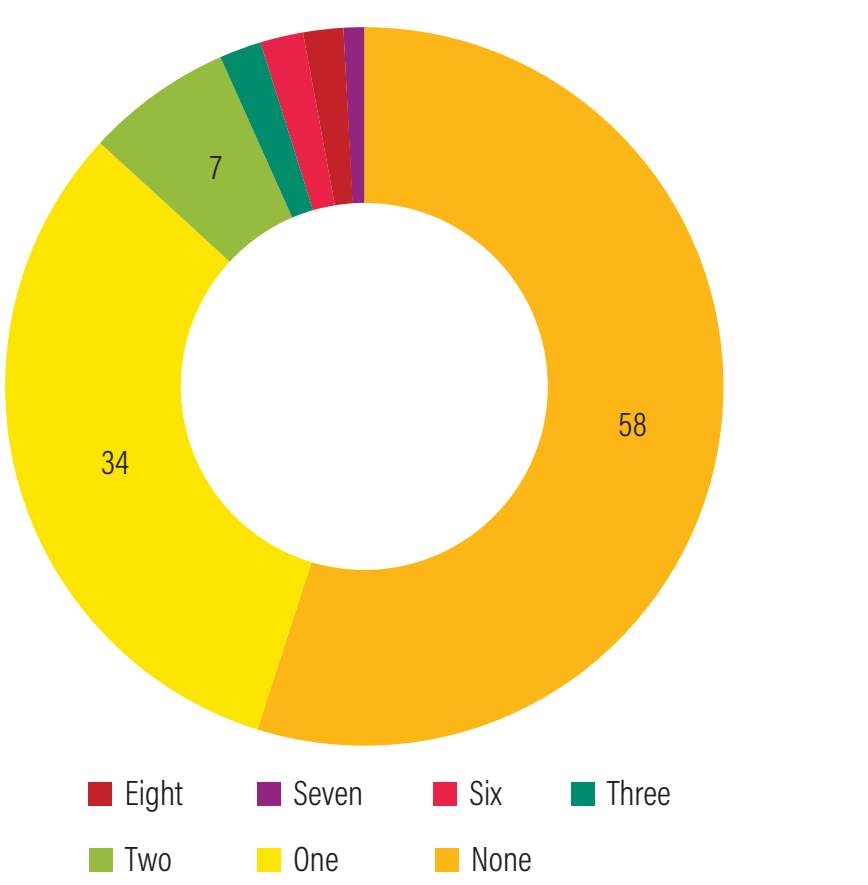

Note: Of the 106 studies reviewed, 58 were not specific to any commodity and only 2 studies covered all eight commodities; 34 studies were specific to a single commodity. Source: WRI India analysis. 
Figure 8 | Number of Publications by Type of Data Source

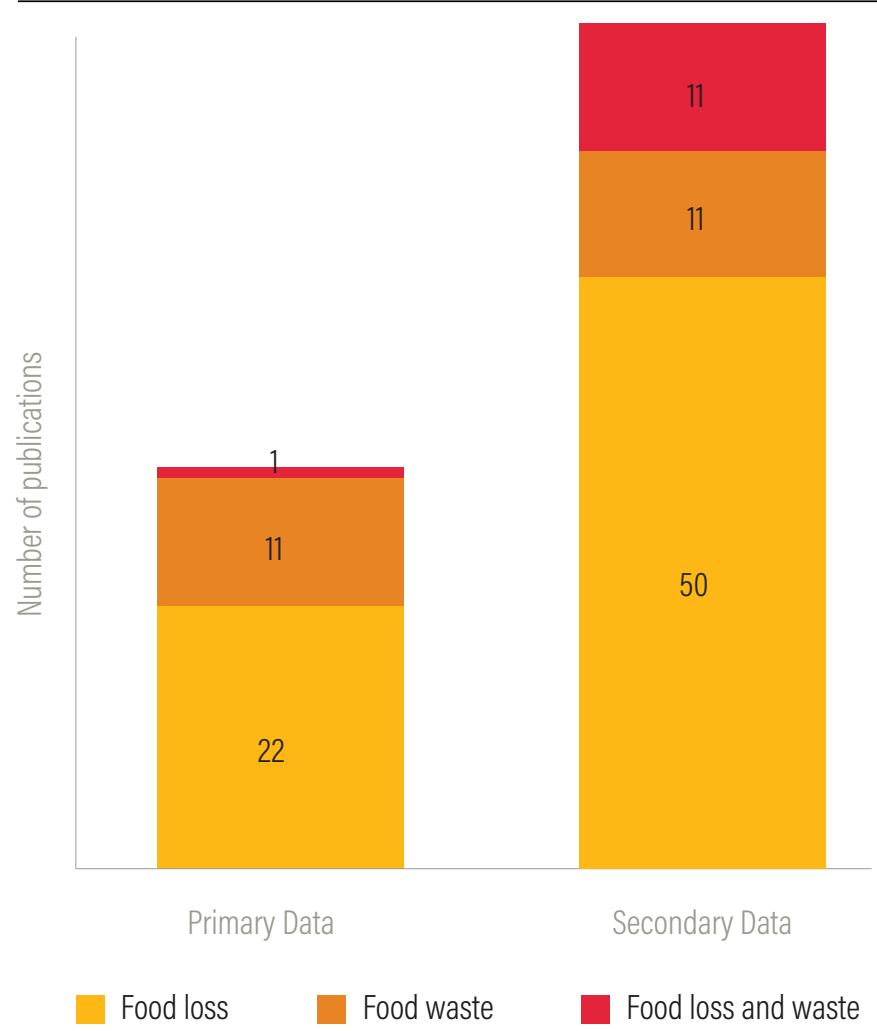

Note: As many as 72 publications relied on secondary data; only 22 publications on food loss and 11 for food waste, respectively, used primary data (mainly behavioral studies). Source: WRI India analysis.

\section{Figure 9 | Number of Publications by State}

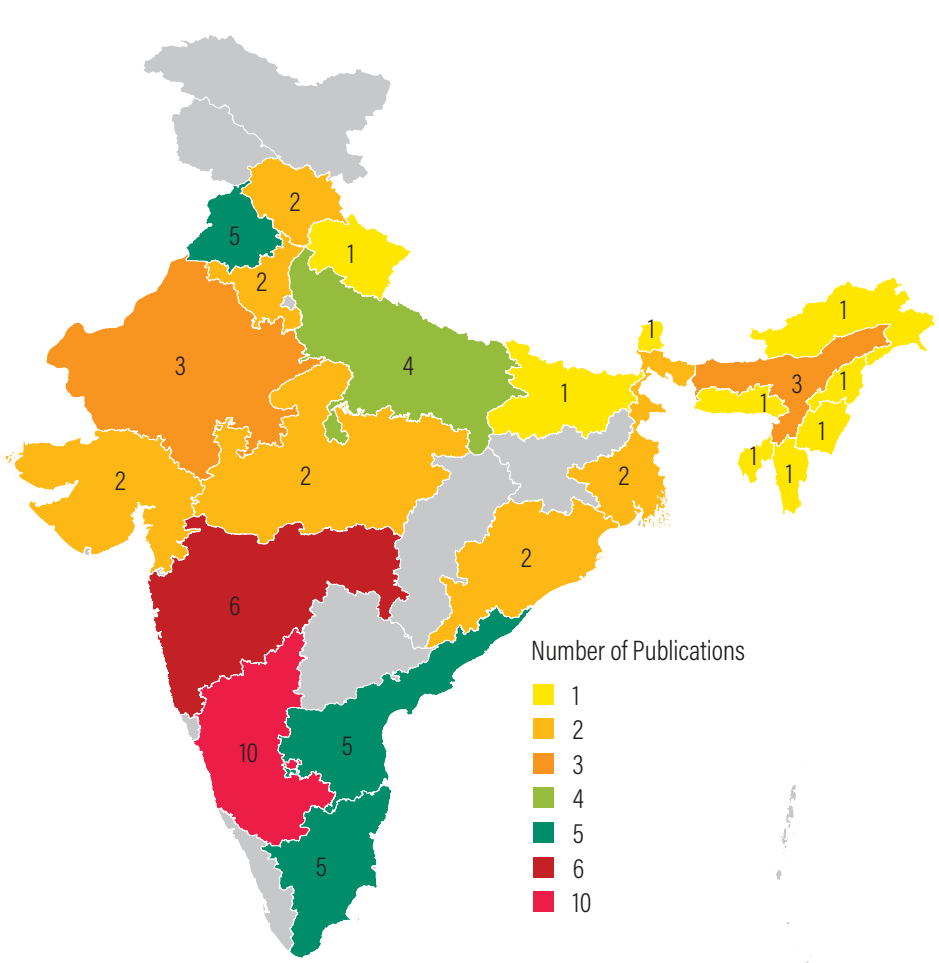

\section{FOOD LOSS IN INDIA}

\section{National Loss Estimates}

India is one of the few countries to have conducted two rounds of comprehensive national surveys on food loss in the last decade. The Union Government has been leading the assessment of post-harvest losses since 1968 when the Panse Committee reported 9.33 percent losses in selected food grains. These included losses during threshing (1.68 percent), transportation (0.15 percent), processing (0.92 percent), rodents (2.50 percent), birds (o.85 percent), insects ( 2.55 percent), and moisture (o.68 percent) (Parliament, Rajya Sabha 2001). In 1973-74, the Directorate of Marketing and Inspection (DMI) under the Ministry of Agriculture and Farmers Welfare (MoAFW) conducted a large-scale sample survey that estimated 5 percent losses of food grains (Parliament, Rajya Sabha 2001). DMI repeated the survey in 25 states across India during the period 1996-99 and reported losses ranging from 1.79 percent in wheat to 7.14 percent in lentils (DMI 2002). These early studies focused mainly on estimating losses in selected food grains, mainly cereals and pulses, and were based on data collected through interviews without any actual observation or measurement of losses. This was the post-Green Revolution period when India was trying to achieve self-sufficiency in food grain production.

The year 2005 is a milestone in the measurement of losses in the Indian context, as ICAR instituted the first comprehensive nationwide assessment of harvest and post-harvest losses for 46 major agriculture crops, ${ }^{3}$ including food grains and perishable commodities such as fruits, vegetables, and livestock produce. The study was a joint effort between the All India Coordinated Research Project on Post Harvest Technology and the Indian Agricultural Statistics Research Institute (IASRI). The data were collected from across India during 2005-2007 through a stratified, three-stage random sampling survey. The survey covered 106 districts spread across 14 of India's 15 agro-climatic zones (excluding islands), and used interviews as well as actual observations from a subsample (Nanda et al. 2012). In 2013-14, commissioned by the Ministry of Food Processing Industries (MoFPI), ICAR repeated the survey in collaboration with the Central Institute of Post-Harvest Engineering and Technology (CIPHET) and IASRI. This survey, involving 45 crops (Jha et al. 2015), is henceforth referred to as the ICAR-CIPHET study. Figure 10 summarizes the scope and timeline of the national-level food loss assessment studies. 


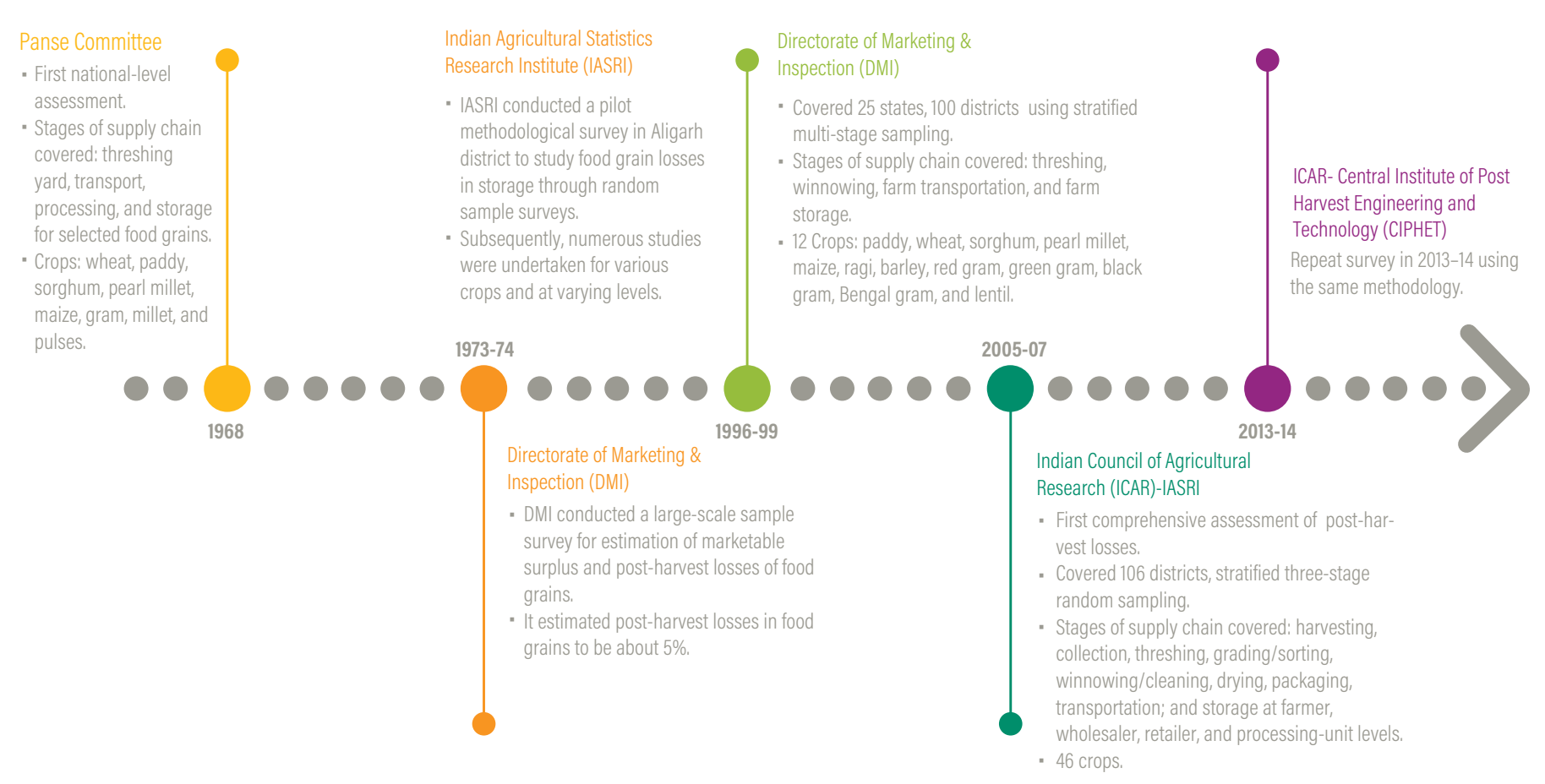

Source: WRI India analysis.

Table 2 compares the loss estimates for major commodity groups from the two rounds of the ICAR surveys. Overall, the losses were lowest for cereals; the highest losses were reported for oilseeds, followed by fruits and vegetables. The ICAR-CIPHET study compared the changes between the two surveys statistically and reported that compared to 2005-07, losses during 2013-14 had "fallen significantly for wheat, mustard, groundnut, mango, guava, mushroom, tapioca, arecanut, black pepper, and coriander. The estimated losses, however, had significantly increased for maize, sorghum, chickpea, soybean, sunflower, citrus, sapota, cauliflower, cashew, marine fish, meat, and poultry meat. For the remaining commodities, the changes in loss were not statistically significant at a five percent level of significance" (Jha et al. 2015). The average losses for food grains, oilseeds, and fruits and vegetables together were found to range between 3.08 percent and 15.88 percent in $2103-14$. The study indicated that overall losses had fallen by about 2 percent since the previous study in 2005-07, despite a tremendous increase in production.

The ICAR-CIPHET study reported that the losses were found to be higher in the eastern plateau and hills region (the tribal belt of India, comprising
Table 2 | National Food Loss Estimates, 2005-2014

\begin{tabular}{l|l|l}
\hline CoMmoDITY & $\mathbf{2 0 0 5 - 0 7}$ & $\mathbf{2 0 1 3 - 1 4}$ \\
\hline Cereals & (Percentage of production) \\
\hline Pulses & $3.87-5.93$ & $4.65-5.59$ \\
\hline Oilseeds & $4.28-6.04$ & $6.36-8.41$ \\
\hline Fruits & $5.77-18.04$ & $6.70-15.88$ \\
\hline Vegetables & $2.75-10.06$ & $3.08-9.96$ \\
\hline Eggs & $6.88-12.47$ & $4.58-12.44$ \\
\hline Milk & 6.55 & 7.19 \\
\hline Meat (Sheep \& Goat) & 0.77 & 0.92 \\
\hline Inland Fishery & 2.23 & 2.71 \\
\hline Marine Fishery & 6.92 & 5.23 \\
\hline
\end{tabular}

Source: Data for both 2007 and 2014 are taken from the ICAR-CIPHET 2013-14 study (Jha et al. 2015). 
Jharkhand, Chhattisgarh, Odisha, and the eastern part of Maharashtra) and the east coast (coasts of Odisha, Andhra Pradesh, and Tamil Nadu) (Jha et al. 2015).

It is remarkable that there have been two rounds of nationwide comprehensive loss assessment studies in India in a period of 10 years. The loss estimates from the ICAR studies are the most widely used, both in India and outside (see Section 6). The ICAR studies provide a vital benchmark for post-harvest loss measurement in the country. However, it is not evident from the studies reviewed how the findings have been used in decisionmaking by any of the stakeholders, including the government, private sector, academia, NGOs, or civil society.

\section{Comparability of Loss Estimates}

In addition to the two comprehensive surveys undertaken by the ICAR, there have been numerous food loss studies conducted on a more limited geographical or crop coverage scale. To what extent can these contribute to the overall picture? This section compares the loss estimates from the ICAR national studies with key subnational and regional studies on post-harvest losses. The literature review found 22 studies (including the two ICAR studies) that contained original data on post-harvest losses, though only 7 are peer reviewed (Appendix C). Most of these studies (16 studies) have been conducted by experts and scientists working at government-affiliated institutions, such as the state agriculture universities (Punjab Agriculture University and Tamil Nadu Agriculture University); Agro-Economic Research Centres (AERCs); Indian Institute of Horticultural Research; University of Agricultural Sciences (UAS); and the Small Farmers' Agribusiness Consortium (SFAC).

We use the example of the mango supply chain to see whether loss estimates can be compared across the studies. There were seven studies that include loss estimates for mango, with figures ranging from 9.2-45 percent (Table 3).

Table 3 | Estimates of Losses in the Mango Supply Chain

\begin{tabular}{|c|c|c|c|c|c|}
\hline DATA SOURCE & LOCATION & $\begin{array}{l}\text { LOSS TYPE: } \\
\text { QUANTITATIVE/ } \\
\text { QUALITATIVE }\end{array}$ & METHODOLOGY & SUPPLY CHAIN STAGES COVERED & $\begin{array}{l}\text { ESTIMATED LOSS } \\
(\%)\end{array}$ \\
\hline FA0 2018b & $\begin{array}{l}\text { Andhra } \\
\text { Pradesh }\end{array}$ & $\begin{array}{l}\text { Quantitative \& } \\
\text { Qualitative }\end{array}$ & Case study, interviews & $\begin{array}{l}\text { Fresh fruit: harvesting, sorting, } \\
\text { transport, retail } \\
\text { Pulp: harvesting, sorting, grading, } \\
\text { transport, ripening (traditionally } \\
\text { or in chambers) }\end{array}$ & $40.0-45.0$ \\
\hline $\begin{array}{l}\text { NCCD (DFI } \\
2017, \text { vol. 3) }\end{array}$ & $\begin{array}{l}\text { Uttar Pradesh, } \\
\text { Karnataka, } \\
\text { Haryana }\end{array}$ & Quantitative & Not available & $\begin{array}{l}\text { Harvest farm gate, post-harvest, } \\
\text { handling, transport, wholesale } \\
\text { level }\end{array}$ & $18.0-31.0$ \\
\hline $\begin{array}{l}\text { ICAR 2005-07 } \\
\text { (Nanda et al. } \\
\text { 2012) } \\
\text { ICAR-CIPHET } \\
\text { (Jha et al. 2015) }\end{array}$ & $\begin{array}{l}\text { All-India, eight } \\
\text { agro-climatic } \\
\text { zones }\end{array}$ & Quantitative & $\begin{array}{l}\text { Multi-stage stratified } \\
\text { sampling, interviews, } \\
\text { and actual observa- } \\
\text { tion }\end{array}$ & $\begin{array}{l}\text { Farm operations (harvesting, } \\
\text { collection, sorting, packaging, } \\
\text { transport); storage (farm, whole- } \\
\text { sale, retail, processing) }\end{array}$ & 12.7 \\
\hline Sab et al. 2017 & Karnataka & Quantitative & $\begin{array}{l}\text { Simple random sam- } \\
\text { pling, interviews }\end{array}$ & $\begin{array}{l}\text { Farm level, wholesale market, } \\
\text { retailing, storage, consumer, } \\
\text { processing unit }\end{array}$ & 34.0 \\
\hline $\begin{array}{l}\text { Murthy et al. } \\
2009\end{array}$ & $\begin{array}{l}\text { Andhra } \\
\text { Pradesh }\end{array}$ & Quantitative & Interviews & $\begin{array}{l}\text { Local marketing: field and assem- } \\
\text { bly, wholesale, retail }\end{array}$ & 29.7 \\
\hline $\begin{array}{l}\text { Srinivas et al. } \\
1997 \text { as cited in } \\
\text { Jha et al. } 2015\end{array}$ & Karnataka & Quantitative & Interviews & $\begin{array}{l}\text { Farm level, transport, storage, } \\
\text { storage (retail) }\end{array}$ & $14.4-17.9$ \\
\hline
\end{tabular}


The lowest losses (9.2 percent) are reported in the ICAR-CIPHET study, which are the average losses from a large sample across eight agro-climatic zones. The highest losses (45 percent) are reported in the FAO (2018b) study, which looked at two districts in Andhra Pradesh using a case study approach. The estimates are too broad to be compared, even with both studies being done in Andhra Pradesh. Part of the ICAR-CIPHET study took place in Agro-Climatic Zone (ACZ) 11 (East Coast Plain and Hills), which includes Andhra Pradesh, where it found losses of 9.72 percent, whereas the FAO study found losses of 45 percent in the same state. Therefore, the losses in mango cannot be compared across geographies.

Each study also estimates losses at different stages of the supply chain (Appendix D). The FAO study (2018b) finds the highest losses during harvesting and transport in the fresh fruit supply chain (15 percent for each), whereas the highest losses in the pulp supply chain occur in the traditional ripening process (19 percent). The ICAR 2005 study (Nanda et al. 2012) identified harvesting to be the stage when most losses occurred (4.1 percent), whereas the ICAR-CIPHET 2013-14 study (Jha et al. 2015) found that sorting and grading resulted in the highest losses (3.26 percent). Srinivas et al. (1997, as cited in Jha et al. [2015]) reported maximum losses in storage at the retail level, whereas Sab et al. (2017) found the highest losses occurring during farm-level operations (8.44 percent). This comparative exercise therefore fails to reveal any single part of the mango supply chain that is a loss hotspot.

This huge variation in estimates is largely the result of varying definitions of food loss as well as the metrics used for measuring loss across the studies. For instance, the stages of the supply chain captured for the estimation of loss are different in all seven studies. The terms used to describe the supply chain stages also vary, which makes the results largely incomparable. Moreover, only the FAO study (2018b) included both quantitative (mass) and qualitative (nutrient) loss in their measurements and assessed the critical loss points in the supply chain stages. Other studies included only the quantitative loss in the supply chain. Notably, the ICAR studies collected data based on actual observation or measurement of losses, whereas the other studies aggregated self-reported data from personal interviews with farmers, traders, and processors.

What is the situation for rice? Eight studies report loss estimates for rice, and these range from 1.8 percent (Kannan 2014) to 11 percent (GoI 1971, cited in Jha et al. 2015). The most recent loss estimate is 7.4 percent (FAO 2018c). As with mango, however, the total loss estimates in rice are too varied and are not comparable because of the diverse definitions and measurement frameworks used. The studies mainly focus on farm-level lossesthere is no information on losses in the supply chain beyond the farm. However, ranking the studies' on-farm loss estimates shows that most losses occur during harvesting, followed by storage (Appendix E).

Despite the lack of comparability, there is useful information in the individual studies that can be improved on as we move forward.

\section{Gaps to Be Filled}

Though the ICAR surveys provide very useful data and analysis on the quantum of losses for each stage of the supply chain and in diverse Indian geographies, they suffer from certain limitations that have been pointed out in the literature. They include only the first-mile storage losses; losses in long-haul transport (and associated handling and storage losses) to terminal markets are not included (DFI 2017). Thus, the ICAR data might be underestimating the losses by not including all the stages of the supply chain. The authors of the ICAR study acknowledged that the losses due to lack of storage facilities, proper handling, and transport are highly variable in time and space, and a special effort would be required to include them. The studies also did not include losses due to weather aberrations in isolated locations or market gluts (Jha et al. 2015). The latter are in any case difficult to incorporate in the research methodologies. Furthermore, the ICAR assessment included only quantitative loss; qualitative loss was not targeted in the methodology.

In sum, the available estimates in the literature are too thin, and too different in their approaches, to allow the development of systematic data on losses in the food supply chain that can inform evidence-based policymaking and action. It is not possible to:

ascertain the magnitude of losses from food production at the national, regional, or subregional level due to the different metrics and measurement methods deployed in these studies (except for the ICAR studies, which might be underestimating losses as discussed above);

- identify the regional hotspots or critical loss points in the supply chain that may need targeted intervention;

- view temporal trends (increase or reduction in losses over time)-except for the ICAR studies;

pinpoint the crops or commodities that experience the highest losses in terms of quantity, quality, or economic value; and 
- identify the actors in the value chain who are crucial to curbing losses.

In the absence of such information, effective management of food loss is unlikely. There is a need to standardize measurement frameworks so that they can be employed on a systematic basis to measure and report on food losses. In addition, multiple stakeholders-producers, transporters, agro-processors, and so on-need to be involved in the research, as they are key to reducing losses along value chains.

\section{Key Drivers and Solutions}

In addition to consistent data on the extent of losses, systematic studies on the causes of food losses are equally important if we are to find solutions. A wide range of literature is available on the reasons for postharvest losses in India. The major issues and challenges discussed in the studies we reviewed include the following (NAAS 2019; FAO 2018b, 2018c; Ghosh et al. 2016; Jha et al. 2015; SFAC 2012):
- Poor harvesting and threshing techniques

- Poor post-harvest handling

- Lack of suitable and adequate storage infrastructure (storage in the open, farmers sometimes using road surfaces to dry their crop)

- Lack of packing houses, cold chain, and on-farm processing facilities

- Fragmented supply chains

- Uncertain returns, with farmers as a result either not harvesting or abandoning their produce

Of these, the three main drivers of food losses identified in the reviewed studies were related to poor storage facilities (including pest management), poor transportation at different stages of the food supply chain, and harvesting techniques (Figure 11). Other reasons, which were not prominent in the reviewed literature, but are important, include market dynamics and those related to contemporary farming practices such as small farm holdings, low capital, and monocropping.

Figure 11 | Causes of Post-harvest Losses in the Reviewed Studies

\begin{tabular}{|c|c|c|c|c|c|c|}
\hline & $\begin{array}{l}9898989 \\
\text { FARM } \\
\text { OPERATIONS }\end{array}$ & STORAGE & $\begin{array}{l}\text { PROCESSING AND } \\
\text { PACKAGING }\end{array}$ & TRANSPORTATION & $\begin{array}{l}\text { SUPPLY CHAIN AND } \\
\text { MARKET IDYNAMICS }\end{array}$ & OTHERS \\
\hline 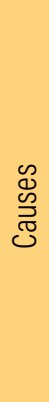 & $\begin{array}{l}\text { Poor harvesting } \\
\text { techniques (12), } \\
\text { Labor shortage } \\
\text { (2), Defects during } \\
\text { sorting (3), } \\
\text { Mono cropping (1) }\end{array}$ & $\begin{array}{l}\text { Improper storage } \\
\text { (24), Lack of pest } \\
\text { management (15) }\end{array}$ & $\begin{array}{l}\text { Traditional ripen- } \\
\text { ing practices (1), } \\
\text { Inappropriate } \\
\text { processing (4), } \\
\text { Lack of processing } \\
\text { units (1), Improper } \\
\text { packaging (7) }\end{array}$ & $\begin{array}{l}\text { Poor transporta- } \\
\text { tion (14), Improper } \\
\text { roads (2), Delivery } \\
\text { channels (1) }\end{array}$ & $\begin{array}{l}\text { Market glut (5), Lack } \\
\text { of information and } \\
\text { transparency (3), } \\
\text { Lack of access to } \\
\text { market (2), Overpro- } \\
\text { duction (2), Frag- } \\
\text { mented supply chain } \\
\text { (2), Many intermedi- } \\
\text { aries (2), Lack of cold } \\
\text { chain (4) }\end{array}$ & $\begin{array}{l}\text { Extreme heat } \\
(4), \text { Heavy } \\
\text { rainfall (2), } \\
\text { Low capital (1), } \\
\text { Small farm } \\
\text { holding (1) }\end{array}$ \\
\hline $\begin{array}{l}\frac{2}{0} \\
\text { 을 } \\
\text { 응 }\end{array}$ & $\begin{array}{l}\text { Mechanized farm } \\
\text { operations (7), } \\
\text { Capacity building } \\
\text { of farmers (16) }\end{array}$ & $\begin{array}{l}\text { Multi-commodity } \\
\text { cold storage (12), } \\
\text { Near-farm storage } \\
\text { solutions (1), } \\
\text { Integrated pest } \\
\text { management (8) }\end{array}$ & $\begin{array}{l}\text { Village cottage } \\
\text { industries (2), } \\
\text { Specialized low- } \\
\text { cost packaging (5) }\end{array}$ & $\begin{array}{l}\text { Rail and reefer } \\
\text { transport (2) }\end{array}$ & $\begin{array}{l}\text { Direct linkage farm } \\
\text { gate to consumer (1), } \\
\text { Develop efficient and } \\
\text { transparent supply } \\
\text { chain (5), Decentral- } \\
\text { ized procurement (1), } \\
\text { Developing cold } \\
\text { chains-pack houses } \\
\text { and reefer transport } \\
\text { (2) }\end{array}$ & $\begin{array}{l}\text { Farmer } \\
\text { Producer } \\
\text { Organisations } \\
\text { (FPOs) (1) }\end{array}$ \\
\hline
\end{tabular}


- Over 80 percent of raw turmeric was left unsold in Kandhamal in Odisha due to a fall in prices in the 2020 season because of the lockdown (Barik 2020).

- The food delivery website MilkBasket lost 15,000 liters of milk and $10,000 \mathrm{~kg}$ of vegetables in a single day after delivery agents faced "harassment by authorities" and "50+ communities" denied them entry (Sushma 2020).

- Farmers in the Belagavi district of Karnataka dumped thousands of liters of milk in a river as they could not reach their customers due to the lockdown (Sushma 2020).

- In the four months between January 1 and May 1, 2020, the stocks of rice and wheat stored in government godowns (grains not "readily issuable" including partially spoiled and damaged grain) increased from 720,000 metric tons to 7,180,000 metric tons (Rawal et al. 2020).

- With international exports grinding to a halt and stricter rules governing transportation, the Alphonso mango farmers in the Konkan region were staring at severe losses. The slump in trade was also visible at the APMC in Vashi in Maharashtra, with just a handful of vehicles carrying mangoes to the market (Menon 2020).

- The Vegetables Growers Association of India estimates that 30 percent of ready-to-harvest crops were left to rot during the lockdown, in contrast to around 5 to 10 percent that is typically wasted on Indian farms, according to Sudha Narayanan, an economist at the Indira Gandhi Institute of Development Research (Abraham 2020).

- A survey conducted by the Indira Gandhi Institute of Development Research of around 370 farmers across nine Indian states found that among those who had harvested some produce this season, 29 percent were still holding on to it; 13 percent had sold the harvests at throwaway prices; and about 7 percent reported that they had to let the produce go to waste (Narayanan 2020).

Recently, the lockdown enforced by the COVID-19 pandemic has affected India's already fragmented food supply chains due to a shortage of wage laborers for harvesting the rabi crop (winter cropping season from October to March), loading and unloading, as well as transportation. These have all exacerbated food losses (Box 2).

The reviewed studies list a range of solutions for managing food losses. These are summarized in Figure 12. The causes and solutions outlined in the reviewed studies are wide-ranging, but not based on systematic evidence or data. Furthermore, there is no scientific documentation of the cost-effectiveness, compatibility, complexity, or the impact of existing tools and technology on loss reduction. For example, several studies focused on improving farm operations to manage losses by mechanizing harvesting and threshing, but its impact on loss reduction was not documented. Institutions such as CIPHET, Tamil Nadu Agricultural University (TNAU), Indian Agricultural Research Institute (the Pusa Institute), Maharana Pratap University of Agriculture \& Technology (MPUAT), and so on, have developed many tools and equipment for postharvest management and primary processing of crops, but only a few are mentioned in the reviewed literature. Thus, it is not possible to ascertain the adoption rate of technology developed in India vis-à-vis that developed outside India, or to assess the effectiveness of available technology in reducing food loss.
There is growing momentum in the private sector for introducing low-cost solutions, leveraging technology, and devising innovative business models in the areas of harvesting, storage, primary processing, and market linkage (Ganesh et al. 2018). However, the role, potential, and impact of the private sector in addressing food loss needs more research.

\section{Gaps to Be Filled}

There are several research gaps to be filled if we are to identify robust solutions for food loss in India:

- Consistent information on hotspots and critical loss points in the food supply chains (discussed above). Without this, it is hard to understand what is driving food losses, and therefore it is difficult to find effective solutions.

- Key causes and solutions specific to smallholder farmers, women, and other social groups.

- The costs and benefits of existing interventions to manage losses.

- The role of information technologies and links between technology and clean energy solutions in managing food loss.

The role, potential, and impact of the private sector in managing loss. 
Without filling these gaps, practical strategies and interventions to manage food losses may not be effective in addressing the root causes.

\section{Government Policy Interventions}

There is very limited policy analysis of food loss in the reviewed studies, apart from NAAS (2019), DFI (2017), NCCD (2015), UJA (2019), and Ganesh et al. (2018). Agriculture is a state subject in India, but the Union Government plays a supportive role by formulating policy guidelines and advice and allocating funds. Several schemes are facilitated by the Government of India for strengthening post-harvest management infrastructure, particularly for storage and cold chain (Table 4). However, no data are available on whether these schemes have been successful in reducing losses.

Both the national commission of farmers set up in 2004 and the Dalwai Committee on Doubling Farmers' Income (DFI) in 2017 recommended several measures to improve post-harvest infrastructure in order to reduce loss and waste. ${ }^{4}$ However, no information is available on the systematic uptake of these suggestions at the policy level.

Most recently, in May 2020, the Finance Minister announced an INR 1 trillion (USD 13.5 billion $^{5}$ ) agriculture infrastructure fund as part of the Atmanirbhar Bharat Abhiyan stimulus package to deal with the COVID-19 crisis. The aim was to provide a mediumto-long-term debt financing facility for setting up cold chains and post-harvest management infrastructure at the farm gate and aggregation points. The fund, financed and managed by the National Bank for Agriculture and Rural Development (NABARD), will be made available to primary agriculture cooperative societies, farmer producer organizations, entrepreneurs, and start-ups (The Hindu 2020). NABARD provides loans and subsidies for warehouses, silos, cold-chain facilities, upgrading marketing infrastructure, and so on.

As seen from Table 4, the development of post-harvest infrastructure is facilitated through several schemes implemented by multiple departments and agencies. Agri-logistics and post-harvest management in India do not come under one dedicated ministry or government department. This, combined with lack of data, can result in fragmented approaches. For instance, the Government of India has been promoting cold-chain infrastructure development through several schemes and incentives, but these are highly fragmented and concentrated on limited areas and crops. Most cold-chain infrastructure is targeted at potatoes $(85-90$ percent of capacity), and two-thirds of cold-chain storage facilities are in Uttar Pradesh and West Bengal (UJA 2019). The technology is now outdated and is not even maintaining the daily temperature properly (Kumar 2014).

The Dalwai Committee argued that "the financial assistance offered by government for marketing infrastructure focused primarily on building cold-storage capacity but did not address the post-storage link with consumption points" (DFI 2017). The farm-level modern pack houses and ripening chambers, and transportation through reefer vehicles to expand market reach, are the missing links in cold-chain infrastructure integration that will minimize the loss of perishable products (NCCD 2015). The absence of data on hotspots and critical loss points is further validated by the Dalwai Committee: "The majority of cold storages for storing fresh fruits \& vegetables have been set up on the basis of ad hoc advice of suppliers of plant and machineries for refrigeration and cooling system and thermal insulation materials under consultancy services provided by chartered accountants who prepared bankable projects for securing bank loans" (DFI 2017). This is further compounded by the presence of varied stakeholders promoting cold chain. A clear need has emerged for "developing a National Policy on Cold Chain to provide underlying direction for a long-term approach to holistic infrastructure creation" (NCCD 2015).

As food supply chains cut across state boundaries, this demands overall intervention by the Union Government. Several critical factors, such as food prices, are also determined centrally. The states have a more important role in designing and implementing context-specific interventions to reduce food loss and waste; however, there might be greater oversight and/or success if a single national department were responsible for food loss and waste in the country.

Even though the states have a key role in addressing losses at various stages of the supply chain, only a few of the reviewed studies analyzed state-specific interventions. The FAO (2018a, 2018b, 2018c) case studies on chickpea, mango, and rice described the schemes implemented by Andhra Pradesh in combination with the Union Government to improve the value chains for these commodities by promoting precision farming, improving post-harvest practices by the use of farm machinery and tools, providing plastic crates, and establishing grading, packing, and processing units at a 50 percent subsidy. It would be useful to undertake an in-depth policy analysis at both the union and state levels. 
Ministry of Agriculture and Farmers Welfare, Department of Agriculture, Cooperation, \& Farmers Welfare (DAC\&FW)

- National Cooperative Development Corporation (NCDC)

- Directorate of Marketing and Inspection (DMI)

- Small Farmers' Agri-Business Consortium (SFAC)
- Mission for Integrated Development of Horticulture (MIDH)

- National Horticulture Mission (NHM)

- National Horticulture Board (NHB)

- Horticulture Mission for North East \& Himalayan States (HMNEH)
- Post-harvest management (especially cold chain), processing, and marketing of horticulture produce

- Storage infrastructure
Ministry of Food Processing Industries (MoFPI)
- Central Sector Scheme Pradhan Mantri Kisan Sampada (Scheme for Agro-Marine Processing and Development of AgroProcessing Clusters)
- Mega food parks

- Integrated cold chain and value addition infrastructure

- Food safety and quality assurance infrastructure

- Infrastructure for agro-processing clusters
Ministry of Consumer Affairs, Department of

Food and Public Distribution

- Indian Grain Storage Management \& Research Institute (IGMRI)

- Central Warehousing Corporation (CWC)

- Warehousing Development and Regulatory Authority (WDRA)

- Food Corporation of India (FCI)

- State Government agencies
- Private Entrepreneurs Godown (PEG) Scheme

- Scheme for construction of modern steel silos

- Central Sector Scheme (erstwhile Plan Scheme)
Ministry of Commerce and Industries, Department of Commerce

- Agricultural and Processed Food Products Export Development Authority (APEDA)
Financial assistance to exporters for establishment of post-harvest infrastructure integrated pack house, purchase of insulated reefer transport/mobile pre-cooling units, etc.

Source: Data collated from the websites of the relevant ministries and institutions: Gol 2021a-2021i; Department of Agriculture and Cooperation 2021; Department of Agriculture Cooperation \& Farmers Welfare 2021a, 2021b; Department of Food \& Public Distribution 2021a, 2021b; MoFPI 2021

The recent reforms and amendments by the Union Government have led to the passing of three bills that aim to change the way agricultural produce is marketed, sold, and stored across the country. ${ }^{6}$ However, the outcomes of the three bills and their subsequent impact on reducing losses, if any, cannot be ascertained in the immediate future.

\section{Gaps to Be Filled}

For government interventions to be more successful at reducing food loss in India, the following lacunae, identified in our analysis of the reviewed studies, have to be addressed:

An uneven policy focus on all links in the food supply chains: Storage issues tend to be the main focus, to the neglect of the post-storage link with consumption points.
The lack of a farm-to-fork approach: The integration of supply chains from farm to fork is essential for more efficient and sustainable food supply chains and to bring "gainful productivity to farming and find solutions to minimize food loss, as also to ensure nutritional security (DFI 2017)."

- The paucity of data-driven schemes and policies: Without the right data on critical loss points in the supply chain, existing interventions are not effective, as reflected in an uneven focus on building stand-alone, single-commodity cold storage facilities without addressing the post-storage link with markets. This fragmented approach could be partly due to the lack of systematic evidence and data on geographical and crop hotspots or due to multiple departments and schemes working in silos. 
Inadequate policy analysis of the existing schemes, interventions, and incentives implemented by the Union Government and different states of India: What is needed is a mapping of schemes and intended stakeholders, and the impact on smallholder farmers, women, and other vulnerable communities.

\section{FOOD WASTE IN INDIA}

Food waste is significantly under-researched in India. The data are largely limited to a few case studies on weddings. There are no household-level data on food waste. Of all the publications reviewed, only 22 were specific to food waste in India, and only 10 generated primary data (Table 5). These studies captured respon- dents' perceptions on food waste but were lacking in any hard data on its extent.

\section{Food Waste Estimates}

A large quantity of food is wasted at weddings and social gatherings in India. According to Srishti Jain, cofounder of Feeding India, a nonprofit organization that collects food from donors and distributes it at their centers in more than 45 cities, over $10-15$ percent of the food is wasted at weddings, which amounts to around $30-50 \mathrm{~kg}$, with the maximum going up to $800 \mathrm{~kg}$ (Sushma 2018).

The volume of food waste is roughly estimated in only one of the studies, which looked at 531 wedding halls in Bengaluru. It revealed that 943 metric tons of highcalorie food are wasted at weddings in Bengaluru city

Table 5 | Primary Studies on Food Waste

\begin{tabular}{|c|c|c|c|c|}
\hline $\begin{array}{l}\text { STATES } \\
\text { COVERED }\end{array}$ & RESEARCH METHOD & $\begin{array}{l}\text { SAMPLE SIZE AND PROFILE OF } \\
\text { RESPONDENTS }\end{array}$ & SECTOR & SOURCE OF DATA \\
\hline Maharashtra & Random sampling & 50 restaurants and hotels & Restaurants & Gadgil 2020 \\
\hline Tamil Nadu & Random sampling & 10 restaurants & Restaurants & Pandian et al. 2019 \\
\hline Maharashtra & Not specified & 63 restaurant owners/managers & Restaurants & Bharucha 2018 \\
\hline Not specified & Random sampling & $\begin{array}{l}7 \text { students, } 2 \text { mess workers, } 1 \text { mess } \\
\text { manager, } 1 \text { mess coordinator, and stu- } \\
\text { dents waiting in mess queue (number not } \\
\text { specified) }\end{array}$ & University mess & $\begin{array}{l}\text { Bandyopadhyay and Dalvi } \\
2017\end{array}$ \\
\hline Karnataka & Random sampling & 14 restaurant owners and 61 consumers & Restaurants & Karanth 2017 \\
\hline Maharashtra & Random sampling & 50 with hospitality background & Restaurants & Sarode and Wani 2017 \\
\hline Maharashtra & $\begin{array}{l}\text { Stratified clustered } \\
\text { and snowball sam- } \\
\text { pling method }\end{array}$ & $\begin{array}{l}966 \text { customers and } 19 \text { hotel senior staff } \\
\text { and owners }\end{array}$ & Restaurants & Gurav 2015 \\
\hline Uttarakhand & Random sampling & $\begin{array}{l}35 \text { low-income group, } 67 \text { middle-income } \\
\text { group, } 42 \text { high-income group, for a total } \\
\text { of } 145 \text { houses from } 11 \text { colonies }\end{array}$ & Households & Grover and Singh 2014 \\
\hline Tamil Nadu & Not specified & 65 (organized and unorganized retailers) & Retailers & Arivazhagan et al. 2012 \\
\hline Delhi NCR & $\begin{array}{l}\text { Stratified random } \\
\text { sampling }\end{array}$ & $\begin{array}{l}410 \text { hospitality industry background, } 410 \\
\text { residential society, } 18 \text { waste management } \\
\text { staff }\end{array}$ & Catering & CCS-IIPA 2011 \\
\hline
\end{tabular}


every year, enough to serve about 26 million people an average Indian meal. Food waste has been found to be greater in buffet systems (22 percent) than in served systems (20 percent) (Gowda et al. 2011 cited in Singh 2014).

\section{Gaps to Be Filled}

Key gaps are the lack of data on the quantity of food wasted nationally, and in various sectors and geographies (rural versus urban) including the household level.

\section{Key Drivers and Solutions}

Defective produce and overproduction were both cited as causes of food waste in the retail, restaurant, and hospitality sectors and mainly in urban centers. Defective produce is food that does not meet the standards set by food manufacturers, restaurants/hotels, and so on. According to retailers in Chennai, food is wasted because it cannot be sold due to inferior quality, including dark spots and decay (Arivazhagan et al. 2012). Restaurant procedures also contribute to waste: "The results from a survey of 63 restaurants in Mumbai show that 75 percent of the restaurants have 10-20 percent extra preparation, which they claim is a safety margin, to enable them to cater to additional crowds. In total, five percent of the restaurants surveyed keep a safety margin of above 30 percent. It was found that the high-end fine dining restaurants make additional preparations as compared to other type of restaurants" (Bharucha 2018).

Key solutions to managing food waste that emerge from the literature are the following:

Reducing, reusing, recycling, and composting food waste (Agarwal and Nag 2013).

Using food banks (Annakshetra, Robin Hood Army, Feeding India) to allocate food that would otherwise be wasted (Bharucha 2018; Agrawal and Nag 2013).

- Installing a public fridge outside restaurants to provide leftovers to anyone in need (Bharucha 2018).

- Conducting food waste audits of restaurants to gather data for efficient management of food resources (Bharucha 2018).

- Implementing initiatives in restaurants such as allowing clients to take away leftovers and choose their serving size, training staff to minimize wastage, hiring food waste auditors, and so on (Bharucha 2018).

- Implementing initiatives in retail outlets such as reducing prices for end stock or offering sales to minimize waste. Informal retailers follow different strategies, such as "second sale to juice shops or other processing shops, keeping goods cool by sprinkling of water, etc.” (Arivazhagan et al. 2012).

\section{Gaps to Be Filled}

The lack of robust data to inform policy and decisionmaking by various actors, including the private sector, is a key gap. Data are needed on:

the main drivers of food waste,

the costs and benefits of existing solutions for managing and reducing food waste, and

- the adoption of recommendations made in the studies at the policy level.

\section{Government Policy Interventions}

At the institutional level, barring a few exceptions, there is still barely any acknowledgment of the problem of food waste. However, there is a growing realization that policy intervention is needed to curb food waste in urban areas. In 2018, the Supreme Court of India expressed concerns over the amount of food and water wasted at weddings and farmhouse parties in Delhi. In response, the Delhi Government issued a "draft policy for holding social functions in hotels/motels and lowdensity residential areas in NCT of Delhi." 7

In 2019, the Food Safety and Standards Authority of India (FSSAI) published the Food Safety and Standards (Recovery and Distribution of Surplus Food) Regulations, under the Food Safety and Standards Act, 2006. These regulations specify the responsibility of the food donor and surplus food distribution organizations engaged in distributing surplus food to any needy person free of charge (Ministry of Health and Family Welfare 2019).

The FSSAI started a social platform in 2017-the Indian Food Sharing Alliance (IFSA) - to promote food donations and stop food waste in urban areas. IFSA has a network of about 80 NGOs and food banks across 188 cities in India (FSSAI n.d.). However, the status of its operations and the resulting impact on food waste reduction are not known.

\section{Gaps to Be Filled}

There is a dearth of policy analysis and policy recommendations to support building a roadmap for reducing food waste in India. Food waste is not on decision-makers' agendas. 


\section{SOCIAL, ECONOMIC, AND ENVIRONMENTAL IMIPACTS}

Research into the social, economic, and environment impacts of food loss and waste in India is negligible.

Any increase in food loss and waste leads to food and nutrition insecurity, especially in situations when supplies are already constrained or households do not have the means to access a secure food supply. More often than not, it is women and individuals in marginalized communities who bear the consequences. When there is limited food, it is traditionally the female members of the household who forgo their meals, leading to nutritional deficiencies (Salcedo La-Viña et al. 2020). Post-harvest operations such as winnowing, drying, and storage are the predominant responsibility of women, and therefore it is important to assess the existing knowledge and level of adoption of post-harvest technology by women (Hegazy 2016). Yet, gender aspects are mentioned in only 11 of the reviewed studies: none of them explores gender comprehensively (FAO 2018a, 2018b, 2018c; Hegazy 2016; Gurav 2015; Kannan 2014; Ramanathan and Parthasarathy 2014; Dutta et al. 2013a, 2013b; Grover et al. 2012).

Only five studies assessed losses by land holding size (Kannan 2014; Dutta et al. 2013a, 2013b; Grover et al. 2012; Hodges et al. 1999). These revealed that postharvest losses are generally higher for marginal and small farmers than for farmers with large land holdings, as the latter have better access to facilities and equipment (Kannan 2014; Dutta et al. 2013a, 2013b; Grover et al. 2012). Only four studies attempted a demographic profile comprising farmers of different farm size categories, age, gender, and marginal social strata such as scheduled castes (SCs), scheduled tribes (STs), other backward castes (OBCs), and general castes (Kannan 2014; Dutta et al. 2013a, 2013b; Grover et al.2012). Most farmers who belong to the marginal castes have limited landholdings and mostly work as farm laborers. Those who do own land have limited resources, which leads to more losses.

The ICAR-CIPHET study is the only one that estimates the implications of food loss for the country's economy. It estimated the economic value of the quantitative loss of 45 crops and livestock produce to be INR 926.51 billion (USD 15.19 billion) at average annual prices in 2014. This is two-and-a-half times higher than the INR 310.63 billion (USD 4.8 billion) budgetary allocations to the MoAFW in that fiscal year. These losses were also higher than the amount received by the MoAFW in FY2018 (INR 790.26 billion; i.e., USD 11.22 billion $^{8}$ ).
Only in FY2019, when the budgetary allocation was the highest ever-at INR 1304.85 billion (USD 17.6 billion ${ }^{9}$ )-did it surpass these losses (Down to Earth 2019). The total losses of INR 926.51 billion do not even include the value of food waste, which was approximately 0.6 percent of India's GDP in FY2014 (Aiyar 2017).

Only two studies estimated the water, land, and carbon footprints of food loss, using data from the ICARCIPHET study (Kashyap and Agarwal 2019; Ravi and Umesh 2018). Kashyap and Agarwal estimated that losses in rice and sugarcane resulted in the largest water loss. The water footprint of the total food losses was $115 \pm 4.15$ billion $\mathrm{m}^{3}\left(105 \pm 3.77\right.$ billion $\mathrm{m}^{3}$ of direct water use and $9.54 \pm 0.38$ billion $\mathrm{m}^{3}$ of indirect water use). Rice accounted for the largest impact on both land and carbon footprints. The total land footprint of food loss was 9.58 \pm 0.4 million hectares (Mha) and the carbon footprint $64.1 \pm 3.8 \mathrm{Mt} \mathrm{CO}_{2}$ eq (Kashyap and Agarwal 2019).

The literature review did not offer many insights into India's progress toward SDG 12.3. No studies examine the relationship between food loss and waste and the SDGs. Food loss and waste potentially has wider implications for achieving other SDGs, but these links remain unexplored in the Indian context.

\section{Gaps to Be Filled}

The following gaps need to be addressed to strengthen the narrative on the social, environmental, and economic dimensions of food loss and waste in India:

The lack of research focused on landholding patterns and gender, as well as the lack of data disaggregated by these themes.

- The scarcity of research on how food loss and waste affects India's food and nutrition security, farmers' incomes, and poverty; and the relationship of loss and waste with social and rural-urban dimensions.

- The lack of studies on the environmental impact of food loss and waste in India.

- The lack of studies that build on and strengthen the findings of the ICAR study on the economic impact of food loss and waste.

- India's lack of reporting on progress toward SDG 12.3. Despite being one of the few nations to have undertaken national-level surveys on food losses, India has not yet begun reporting on SDG 12.3 (NITI Aayog 2019). India has the required expertise and has been playing a crucial role at the global level in the development of methodologies to measure 
and report on food loss and waste..$^{10}$ However, the biggest challenge faced is that food loss and waste is not yet a mandate for any single institution, organization, or government department in India.

\section{CONCLUSIONS AND THE WAY FORWARD}

The challenge of food loss and waste in India is underresearched. Paying more attention to the issue offers immense potential for improving India's food security, economy, and environment. Measuring food loss and waste accurately is essential, as what gets measured gets managed. Yet the measurement of food loss and waste is a complex and costly proposition owing to the wide range of agriculture commodities, distinct measurement traits, multiple stages in the supply chain and processing, and the presence of numerous actors.

In the following sections, we propose three key areas that need attention.

\section{Identifying the Magnitude and Hotspots of Food Loss and Waste in India}

Currently, the analysis is hampered by the lack of common definitions and frameworks, resulting in highly variable and scattered loss estimates for a wide range of commodities and locations. However, as India is divided into 15 agro-climatic zones, collecting and collating data on a wide range of commodities across these diverse zones would be extremely challenging and highly resource intensive. The lack of resources is one of the main deterrents for any institution in India to bringing systematic measurement and reporting of food losses under their mandate (Rawal 2020). ${ }^{11}$ As nationwide surveys can be very costly, they may not be able to cover all dimensions, and cannot be administered on a regular basis. We therefore need to explore the possibility of supplementing nationally representative surveys, such as those conducted by ICAR, with high-precision, more frequent, specific surveys, case studies, and/or needbased rapid assessments in specific crops, geographies, social groups, and food supply chains. These specific surveys could help identify and monitor the critical loss points and hotspots and serve the objectives of the producers, logistics providers, processors, suppliers, and policymakers.

\section{Adopting a Harmonized Yardstick for Measuring Food Loss and Waste}

The surveys mentioned above need to use a harmonized yardstick ${ }^{12}$ or protocol so that they can be compared and interlinked, and complement one other. The global Food Loss and Waste Accounting and Reporting Standard (or FLW Standard) developed by the FLW Protocol ${ }^{13}$ (Food Loss and Waste Protocol 2016) offers a consistent approach to measuring and reporting losses. It could be considered by Indian institutions but will need to be adapted to the Indian context.

Adopting a standard metric will help produce data from different studies that can be compared across time and geographies, making it more useful for decision-makers.

\section{Building a Coalition for Guiding Research and Mobilizing Action}

It is vital that reducing food loss and waste becomes a priority action area for an increasing number of public and private institutions in India. In the absence of any analysis of trade-offs or quantification of the costs and benefits of reducing food loss and waste, it is not easy to justify targeted resource allocations or leverage private investment (Cattaneo et al. 2020). Furthermore, in the absence of clear evidence of the scale of the problem, it is hard to build public and government awareness regarding the need for action.

Setting up a multi-stakeholder action coalition can help foster multi-actor partnerships to put food loss and waste at the top of the agenda in India and develop strategies to manage it. Its role could be to:

put food loss and waste on the research agenda;

foster collaboration and partnerships to manage food loss and waste;

raise awareness of the different dimensions of food loss and waste among diverse stakeholders, and the costs and benefits of action;

develop strategies and mobilize action to reduce food loss and waste; and

support policy and its implementation for sustainable food systems. 


\section{FOOD LOSS}

India AND (crop OR Meat OR Egg OR Fish OR pulse OR grain OR poultry OR Vegetable OR Fruit OR spice OR Milk) AND ("Supply Chain" OR Mandi OR Transport*) AND ("Food Loss" OR "Quality loss" OR damage OR contamin* OR disease OR spoil OR pest OR quant*)

India AND (crop OR Meat OR Egg OR Fish OR pulse OR grain OR poultry OR Vegetable OR Fruit OR spice OR Milk) AND ("Post harvest" OR hoarding OR Storage) AND ("Food Loss" OR "Quality loss" OR damage OR contamin* OR disease OR spoil OR pest OR quant*)

India AND (crop OR Meat OR Egg OR Fish OR pulse OR grain OR poultry OR Vegetable OR Fruit OR spice OR Milk) AND (APMC OR overstock* OR process* OR PDS) AND ("Food Loss" OR "Quality loss" OR damage OR contamin* OR disease OR spoil OR pest OR quant*)

\section{FOOD WASTE}

India AND (Consum* OR Retail* OR Restaurant OR "fast food") AND ("Food waste" OR expir* OR biowaste OR "kitchen waste" OR Leftover OR quant*) AND (Meat OR Egg OR Fish OR cereal OR pulse OR grain OR milk OR poultry OR Vegetable OR Fruit OR spice)

India AND (household OR "shelf life" OR supermarket OR behavio*) AND ("Food waste" OR expir* OR biowaste OR "kitchen waste" OR Leftover OR quant*) AND (Meat OR Egg OR Fish OR cereal OR pulse OR grain OR milk OR poultry OR Vegetable OR Fruit OR spice)

India AND (hotel OR hostel OR cater* OR temple OR afford*) AND ("Food waste" OR expir* OR biowaste OR "kitchen waste" OR Leftover OR quant*) AND (Meat OR Egg OR Fish OR cereal OR pulse OR grain OR milk OR poultry OR Vegetable OR Fruit OR spice)

\section{APPENDIX B: STAKEHOLDER CONSULTATIONS}

\section{STAKEHOLDER CONSULTATION}

Technical Working Group Meeting Total participants: 15, 0ctober 22, 2020, held virtually

Meeting with Prof. Vikas Rawa

September 18, 2020, held virtually

Meeting with Dr. Hukum Chandra October 5, 2020, held virtually

Meeting with Dr. S.N. Jha

September 16, 2020, held virtually

Meeting with Kai Robertson September 30, 2020, held virtually

Meeting with Neel Ghose October 9, 2020, held virtually

\section{PARTICIPANT AFFILIATIONS}

Amity Food and Agriculture Foundation; Jawaharlal Nehru University; India Foundation for Humanistic Development; ICAR-Indian Agricultural Statistics Research Institute (IASRI); FOLU India; Association for Social Advancement; World Food Programme; BAIF; WRI India

Professor, Centre for Economic Studies and Planning, School of Social Sciences, Jawaharlal Nehru University

National Fellow \& Principal Scientist, ICAR-Indian Agricultural Statistics Research Institute

Assistant Director General (Process Engineering), Indian Council of Agricultural Research

Lead Advisor, WRI, Food Loss \& Waste Protocol

Cofounder, Robin Hood Army

\section{OBJECTIVES}

Discuss emerging findings and key recommendations from the literature on tackling food loss and waste in India and the implications of the findings; get feedback on the methodological approach and process followed to understand food loss and waste in India.

Develop an understanding of SDG 12.3 reporting in the Indian context.

Develop an understanding of the methodology adopted for estimating food loss for measurement of SDG 12.3.1 and India's current status in monitoring SDG 12.3.1.

Develop an understanding of the limitations of the ICAR-CIPHET study.

Develop an understanding of the FLW Protocol developed by WRI.

Understand Robin Hood Army's model and interventions in managing food waste in the Indian context. 


\begin{tabular}{|c|c|c|c|c|c|c|c|c|}
\hline $\begin{array}{l}\text { S. } \\
\text { NO. }\end{array}$ & CROPS & $\begin{array}{l}\text { STATES } \\
\text { COVERED }\end{array}$ & $\begin{array}{l}\text { YEAR } \\
\text { (DATA } \\
\text { COLLEC- } \\
\text { TION) }\end{array}$ & SAMPLE SIZE & METHOD & INSTITUTION & CITATION & PURPOSE OF THE STUDY \\
\hline 1 & $\begin{array}{l}\text { Paddy, wheat, jowar, } \\
\text { bajra, maize, ragi, bar- } \\
\text { ley, red gram, green } \\
\text { gram, black gram, } \\
\text { Bengal gram, lentil }\end{array}$ & 25 states & 1996-99 & 15,000 farmers & Interviews & $\begin{array}{l}\text { Directorate of Marketing } \\
\text { and Inspection (DMI) }\end{array}$ & DMI 2002 & $\begin{array}{l}\text { Estimate marketable surplus } \\
\text { and post-harvest losses of } \\
\text { food grains }\end{array}$ \\
\hline 2 & Sorghum & $\begin{array}{l}\text { Karnataka, } \\
\text { Maharashtra, } \\
\text { Andhra Pradesh }\end{array}$ & 1997-98 & 12 villages & $\begin{array}{l}\text { Interviews } \\
\text { and actual } \\
\text { observa- } \\
\text { tion }\end{array}$ & $\begin{array}{l}\text { Natural Resources In- } \\
\text { stitute, Kent, UK; Indian } \\
\text { Grain Storage Manage- } \\
\text { ment and Research } \\
\text { Institute; International } \\
\text { Crops Research Institute } \\
\text { for the Semi-Arid Tropics } \\
\text { (ICRISAT) }\end{array}$ & $\begin{array}{l}\text { Hodges } \\
\text { et al. } \\
1999\end{array}$ & $\begin{array}{l}\text { Understand the factors } \\
\text { responsible for the decline of } \\
\text { production and consumption } \\
\text { of sorghum }\end{array}$ \\
\hline 3 & $\begin{array}{l}\text { Mango, grape, banana, } \\
\text { pomegranate }\end{array}$ & $\begin{array}{l}\text { Andhra Pradesh, } \\
\text { Karnataka }\end{array}$ & $2000-02$ & $\begin{array}{l}120 \text { farmers, } 50 \\
\text { wholesalers, } 60 \\
\text { retailers }\end{array}$ & $\begin{array}{l}\text { Interviews } \\
\text { and actual } \\
\text { observa- } \\
\text { tion }\end{array}$ & $\begin{array}{l}\text { Indian Institute of Horti- } \\
\text { cultural Research (IIHR) }\end{array}$ & $\begin{array}{l}\text { Murthy } \\
\text { et al. } \\
2009\end{array}$ & $\begin{array}{l}\text { Assess post-harvest losses } \\
\text { in major fruits both in physi- } \\
\text { cal and economic terms at } \\
\text { different stages of handling, } \\
\text { and develop strategies to } \\
\text { reduce these losses }\end{array}$ \\
\hline 4 & Maize & Karnataka & 2003-04 & 100 farmers & Interviews & $\begin{array}{l}\text { University of Agricultural } \\
\text { Sciences (UAS) }\end{array}$ & $\begin{array}{l}\text { Basappa } \\
\text { et al. } \\
2007\end{array}$ & $\begin{array}{l}\text { Estimate post-harvest loss in } \\
\text { maize at different stages at } \\
\text { the farm level }\end{array}$ \\
\hline 5 & Rice and wheat & Karnataka & $2003-04$ & $\begin{array}{l}200 \text { cultivators, } \\
40 \text { wholesalers, } \\
40 \text { processors, } \\
\text { and } 40 \text { retailers }\end{array}$ & Interviews & $\begin{array}{l}\text { University of Agricultural } \\
\text { Sciences (UAS) }\end{array}$ & $\begin{array}{l}\text { Basa- } \\
\text { varaja et } \\
\text { al. } 2007\end{array}$ & $\begin{array}{l}\text { Assess the extent and mag- } \\
\text { nitude of losses and identify } \\
\text { the factors responsible for } \\
\text { such losses }\end{array}$ \\
\hline 6 & Sapota & Karnataka & 2006 & $\begin{array}{l}21 \text { farmers, } 32 \\
\text { retailers }\end{array}$ & $\begin{array}{l}\text { Interviews } \\
\text { and actual } \\
\text { observa- } \\
\text { tion }\end{array}$ & $\begin{array}{l}\text { Indian Institute of Horti- } \\
\text { cultural Research (IIHR) }\end{array}$ & $\begin{array}{l}\text { Gajanana } \\
\text { et al. } \\
2006\end{array}$ & $\begin{array}{l}\text { Assess the losses in } \\
\text { post-harvest handling and } \\
\text { marketing of sapota }\end{array}$ \\
\hline 7 & $\begin{array}{l}46 \text { items including } \\
\text { grain, fruits, vegeta- } \\
\text { bles, plantation crops, } \\
\text { spices, and livestock } \\
\text { produce }\end{array}$ & $\begin{array}{l}14 \text { Agro-Climatic } \\
\text { Zones (ACZs) }\end{array}$ & $2005-07$ & 10,600 farmers & $\begin{array}{l}\text { Interviews } \\
\text { and actual } \\
\text { observa- } \\
\text { tion }\end{array}$ & $\begin{array}{l}\text { Indian Council of Agri- } \\
\text { cultural Research (ICAR) }\end{array}$ & $\begin{array}{l}\text { Nanda et } \\
\text { al. } 2012\end{array}$ & $\begin{array}{l}\text { Carry out a systematic } \\
\text { quantitative assessment of } \\
\text { the extent of harvest and } \\
\text { post-harvest losses }\end{array}$ \\
\hline 8 & $\begin{array}{l}\text { Pomegranate and, } \\
\text { onion }\end{array}$ & Maharashtra & $2008-11$ & 87 farmers & Interviews & $\begin{array}{l}\text { Agro-Economic } \\
\text { Research Centre (AERC), } \\
\text { Gokhale Institute of } \\
\text { Politics and Economics }\end{array}$ & $\begin{array}{l}\text { Shroff et } \\
\text { al. } 2011\end{array}$ & $\begin{array}{l}\text { Observe the role of emerg- } \\
\text { ing marketing channels in } \\
\text { agriculture in Maharashtra } \\
\text { and the benefits to producers } \\
\text { and consumers }\end{array}$ \\
\hline 9 & $\begin{array}{l}\text { Tomato, mango, } \\
\text { brinjal, cucurbits, okra, } \\
\text { litchi }\end{array}$ & Uttar Pradesh & 2009 & $\begin{array}{l}180 \text { crop } \\
\text { samples }\end{array}$ & $\begin{array}{l}\text { Interviews } \\
\text { and actual } \\
\text { observa- } \\
\text { tion }\end{array}$ & $\begin{array}{l}\text { World Food Logistics } \\
\text { Organization (WFLO) }\end{array}$ & $\begin{array}{l}\text { Kitinoja } \\
2010\end{array}$ & $\begin{array}{l}\text { Identify appropriate post- } \\
\text { harvest technologies for } \\
\text { improving market access and } \\
\text { incomes for small horticul- } \\
\text { tural farmers in sub-Saharan } \\
\text { Africa and South Asia }\end{array}$ \\
\hline 10 & Wheat and paddy & Punjab & $2010-12$ & 120 farmers & Interview & $\begin{array}{l}\text { AERC, Punjab Agricul- } \\
\text { tural University }\end{array}$ & $\begin{array}{l}\text { Grover et } \\
\text { al. } 2012\end{array}$ & $\begin{array}{l}\text { Estimate the dimension of } \\
\text { losses occurring during the } \\
\text { pre- and post-harvest stages } \\
\text { of paddy and wheat crops }\end{array}$ \\
\hline 11 & Soybean & Rajasthan & 2011-12 & 120 farmers & Interviews & $\begin{array}{l}\text { AERC, Sardar Patel } \\
\text { University }\end{array}$ & $\begin{array}{l}\text { Dutta et } \\
\text { al. 2013a }\end{array}$ & $\begin{array}{l}\text { Assess pre- and post-harvest } \\
\text { losses in soybean crop in } \\
\text { Rajasthan }\end{array}$ \\
\hline 12 & Tur & Gujarat & $2011-12$ & 120 farmers & Interviews & $\begin{array}{l}\text { AERC, Sardar Patel } \\
\text { University }\end{array}$ & $\begin{array}{l}\text { Dutta et } \\
\text { al. 2013b }\end{array}$ & $\begin{array}{l}\text { Assess pre- and post-harvest } \\
\text { losses in tur crop in Gujarat }\end{array}$ \\
\hline
\end{tabular}




\begin{tabular}{|c|c|c|}
\hline $\begin{array}{l}\text { S. } \\
\text { NO. }\end{array}$ & CROPS & $\begin{array}{l}\text { STATES } \\
\text { COVERED }\end{array}$ \\
\hline 13 & $\begin{array}{l}\text { Rice, wheat, tur, and } \\
\text { soybean. }\end{array}$ & $\begin{array}{l}\text { Assam, Gujarat, } \\
\text { Karnataka, Ma- } \\
\text { dhya Pradesh, } \\
\text { Maharashtra, } \\
\text { Punjab, Rajast- } \\
\text { han, Tamil Nadu, } \\
\text { Uttar Pradesh, } \\
\text { West Bengal }\end{array}$ \\
\hline
\end{tabular}

14 Litchi

Bihar 2012-13 N/A

14 ACZs

2013-14 10,700 farmers

Actual

Indian Council of Agri- Kumar et Assess losses at the farm,

observa- cultural Research (ICAR) al. 2016

wholesale, and retail levels

tion

in the supply chain of litchi

in India

$15 \quad \begin{aligned} & 45 \text { items including } \\ & \text { grain, fruits, vegeta- } \\ & \text { bles, plantation crops, } \\ & \text { spices, and livestock } \\ & \text { produce }\end{aligned}$
$16 \quad$ Mango

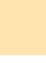

Karnataka 2013-14 120 farmers

Interviews Indian Council of Agri- Jha et al. Conduct a nationwide conand actual cultural Research (ICAR) 2015 current repeat study to asobserva-

tion sess the post-harvest losses of crops and commodities

17 Rice

18 Mango

Andhra Pradesh $2015 \quad$ N/A

Andhra Pradesh $2015 \quad$ N/A

$N / A$

$\begin{array}{ll}\text { Interviews } & \text { Food and Agriculture } \\ & \text { Organization (FAO) }\end{array}$

FAO
$2018 b$

University of Agricultural Sab et al. Estimate post-harvest losses Sciences (UAS); Krishi 2017 of mangoes at different Vigyan Kendra (KVK) stages from harvesting to consumption

FAO Identify the main causes of 2018c food losses in the rice supply chain and suggest potential solutions to mitigate them

Identify the main causes of food losses in the mango supply chain and suggest potential solutions to mitigate them

19 Chickpea Andhra Pradesh $2015 \quad$ N/A
Interviews Food and Agriculture Organization (FAO)

FAO 2018a
Identify the main causes of food losses in the chickpea supply chain and suggest potential solutions to mitigate them

20 Potato, tomato, peas, Himachal onion Pradesh

$\begin{array}{ll}\text { Not } & 50 \text { farmers, } 5 \\ \text { specified } & \begin{array}{l}\text { wholesalers, } 10 \\ \text { retailers }\end{array}\end{array}$

Mehra
Identify the challenges in the and Joshi vegetable supply chain in the 2016 Kumaun region of Uttarakhand, India

\section{Pineapple, citrus,} ginger, turmeric, Tripura, Megha- Not 81 interviews laya, Nagaland, specified with state vegetables, Naga chili, Assam, Manipur, passion fruit, kiwi fruit, Sikkim, Mizoram, large cardamom Arunachal Pradesh government officials, experts, and policymakers. 16 focus group discussions (FGDs) with producers and prominent stakeholders. 60 interviews with retailers and wholesalers

$\begin{array}{lll}22 N / A & \text { N/A } & \text { Not } \\ & \text { speci- } \\ & \text { fied }\end{array}$

FGDs and Small Farmers' Agribusi- SFAC interviews ness Consortium (SFAC) 2012

Conduct a detailed value chain study of Focussed Crop Groups (FCGs) of the North Eastern Region 


\section{APPENDIX D: ESTIMATES OF LOSSES IN MANGO SUPPLY CHAIN}

Table D1 | Estimate of Loss in Mango, Andhra Pradesh

\begin{tabular}{|c|c|c|c|c|c|c|}
\hline \multirow{2}{*}{ SOURCE } & \multirow[b]{2}{*}{ PULP } & \multirow{2}{*}{$\begin{array}{l}\text { HARVESTING, } \\
\text { SORTING, GRADING }\end{array}$} & \multirow[b]{2}{*}{ TRANSPORT } & \multicolumn{2}{|l|}{ RIPENING } & \multirow[b]{2}{*}{ TOTAL LOSS } \\
\hline & & & & $\begin{array}{l}\text { TRADITIONAL } \\
\text { PROCESS }\end{array}$ & $\begin{array}{l}\text { RIPENING } \\
\text { CHAMBERS }\end{array}$ & \\
\hline \multirow[t]{9}{*}{$\begin{array}{l}\text { FAO } \\
2018 b\end{array}$} & Quantity loss (\%) & 12.0 & 0.5 & 19.0 & $3.0-6.0$ & \multirow{9}{*}{$34.5-37.5$} \\
\hline & Quality loss (\%) & 5.00 & NA & 20.0 & 10.0 & \\
\hline & $\begin{array}{l}\text { Product through this } \\
\text { stage (\%) }\end{array}$ & 100.0 & 88.0 & 87.5 & 87.5 & \\
\hline & Loss in FSC (\%) & 12.0 & 0.5 & 19.0 & $3.0-6.0$ & \\
\hline & Fresh Fruit & Harvesting & Sorting/Grading & Transport & Retail & \\
\hline & Quantity (\%) & 15.0 & 5.0 & 15.0 & $5.0-10.0$ & \\
\hline & Quality (\%) & 5.0 & 5.0 & 20.0 & 25.0 & \\
\hline & $\begin{array}{l}\text { Product through this } \\
\text { stage (\%) }\end{array}$ & 100.0 & 85.0 & 80.0 & 65.0 & \\
\hline & Loss in FSC (\%) & 15.0 & 5.0 & 15.0 & $5.0-10.0$ & \\
\hline
\end{tabular}

Note: FSC: Food Supply Corporation.

Table D2 | Estimate of Loss in Mango, Uttar Pradesh, Uttarakhand, Haryana

\begin{tabular}{|c|c|c|c|c|c|c|}
\hline SOURCE & LOSS (\%) & $\begin{array}{l}\text { HARVEST } \\
\text { FARM GATE }\end{array}$ & $\begin{array}{l}\text { POST-HARVEST } \\
\text { HANDLING }\end{array}$ & TRANSPORT & WHOLESALE & TOTAL LOSS \\
\hline $\begin{array}{l}\text { NCCD } 2016 \\
\text { cited in DFI } \\
\text { 2017. Vol. } 3\end{array}$ & Quantity & 2.0 to 4.0 & 8.0 to 12.0 & 5.0 to 10.0 & 3.0 to 5.0 & 18.0 to 31.0 \\
\hline
\end{tabular}


Table D3 | Estimate of Loss in Mango, ICAR Surveys, All-India

\begin{tabular}{|c|c|c|c|c|c|c|c|c|c|c|c|c|c|c|c|}
\hline \multirow[b]{2}{*}{ SOURCE } & \multirow[b]{2}{*}{ REGION } & \multirow[b]{2}{*}{$\begin{array}{l}\text { LOSS } \\
(\%)\end{array}$} & \multicolumn{6}{|c|}{ FARM-LEVEL OPERATIONS } & \multicolumn{6}{|l|}{ STORAGE } & \multirow[b]{2}{*}{$\begin{array}{l}\text { Total } \\
\text { Loss }\end{array}$} \\
\hline & & & $\begin{array}{l}\text { Harvest- } \\
\text { ing }\end{array}$ & $\begin{array}{l}\text { Collec- } \\
\text { tion }\end{array}$ & $\begin{array}{l}\text { Sorting/ } \\
\text { Grading }\end{array}$ & $\begin{array}{l}\text { Pack- } \\
\text { aging }\end{array}$ & $\begin{array}{l}\text { Trans- } \\
\text { port }\end{array}$ & $\begin{array}{l}\text { Sub- } \\
\text { total }\end{array}$ & $\begin{array}{l}\text { Farm-Level } \\
\text { Operations }\end{array}$ & $\begin{array}{l}\text { God- } \\
\text { own }\end{array}$ & $\begin{array}{l}\text { Whole- } \\
\text { sale }\end{array}$ & Retail & $\begin{array}{l}\text { Pro- } \\
\text { cessing }\end{array}$ & $\begin{array}{l}\text { Sub- } \\
\text { total }\end{array}$ & \\
\hline $\begin{array}{l}\text { Nanda } \\
\text { et al. } \\
2012\end{array}$ & India & $\begin{array}{l}\text { Quan- } \\
\text { tity }\end{array}$ & 4.1 & 0.7 & 2.8 & 0.5 & 2.5 & 10.6 & 0.1 & - & 0.9 & 0.9 & 0.2 & 2.1 & 12.7 \\
\hline $\begin{array}{l}\text { Jha et } \\
\text { al. } 2015\end{array}$ & India & $\begin{array}{l}\text { Quan- } \\
\text { tity }\end{array}$ & 2.1 & 0.3 & 3.3 & 0.2 & 1.0 & 6.9 & 0.1 & 0.01 & 0.7 & 1.2 & 0.3 & 2.2 & 9.2 \\
\hline
\end{tabular}

Table D4 | Estimate of Loss in Mango, Karnataka

\begin{tabular}{|c|c|c|c|c|c|c|c|c|}
\hline SOURCE & LOSS (\%) & $\begin{array}{l}\text { FARM-LEVEL } \\
\text { OPERATIONS }\end{array}$ & $\begin{array}{l}\text { WHOLESALE } \\
\text { MARKET }\end{array}$ & RETAILING & STORAGE & CONSUMER & $\begin{array}{l}\text { PROCESSING } \\
\text { UNIT }\end{array}$ & TOTAL \\
\hline $\begin{array}{l}\text { Sab et } \\
\text { al. } 2017\end{array}$ & Quantity & 8.4 & 4.9 & 5.5 & 5.7 & 6.8 & 3.2 & 34.5 \\
\hline
\end{tabular}

Table D5 | Estimate of Loss in Mango, Andhra Pradesh

\begin{tabular}{l|l|l|l|l|l}
\hline SOURCE & LOSS (\%) & $\begin{array}{l}\text { FIELD AND } \\
\text { ASSEMBLY LOCAL } \\
\text { MARKETING }\end{array}$ & $\begin{array}{l}\text { WHOLESALE LOCAL } \\
\text { MARKETING }\end{array}$ & $\begin{array}{l}\text { RETAIL LOCAL } \\
\text { MARKETING }\end{array}$ & $\begin{array}{l}\text { TOTAL LOSS } \\
\text { (LOCAL } \\
\text { MARKETING) }\end{array}$ \\
\hline Murthy et al. 2009 & Quantity & 15.6 & 8.9 & 5.3 & $\mathbf{2 9 . 7}$ \\
\hline
\end{tabular}

Table D6 | Estimate of Loss in Mango, Karnataka

\begin{tabular}{l|l|l|l|l|l|l|}
\hline SOURCE & VARIETY & LOSS (\%) & $\begin{array}{l}\text { FARM-LEVEL } \\
\text { OPERATIONS }\end{array}$ & TRANSPORT & STORAGE & $\begin{array}{l}\text { STORAGE } \\
\text { (RETAIL) }\end{array}$ \\
$\begin{array}{l}\text { Srinivas et al. } \\
\text { 1997, as cited } \\
\text { in Jha et al. } \\
2015\end{array}$ & Alphonso & Quantity & 1.9 & 3.7 & 3.5 & 5.3 \\
\hline
\end{tabular}

Note: Yellow highlight indicates the highest loss in the supply chain.

Source: WRI India analysis. 


\section{APPENDIX E:" ESTIMATES OF LOSSES IN RICE SUPPLY CHAIN WITHIN DIFFERENT}

\section{RESEARCH STUDIES}

Table E1 | Estimates of Loss in Rice, Andhra Pradesh

\begin{tabular}{|c|c|c|c|c|c|c|}
\hline SOURCE & $\begin{array}{l}\text { HARVESTING AND } \\
\text { THRESHING }\end{array}$ & DRYING & TRANSPORT & $\begin{array}{l}\text { STORAGE } \\
\text { (CWC } \\
\text { WAREHOUSE) }\end{array}$ & $\begin{array}{l}\text { STORAGE } \\
\text { (FCI } \\
\text { WAREHOUSE) }\end{array}$ & $\begin{array}{l}\text { STORAGE } \\
\text { (MILL) }\end{array}$ \\
\hline FA0 2018 & 6 & 0.2 & 0.5 & 0.2 & 0.2 & 0.3 \\
\hline
\end{tabular}

Table E2 | Estimates of Loss in Rice, ICAR Surveys, All-India

SOURCE

Farm level operations

\begin{tabular}{|c|c|c|}
\hline Harvesting & 2.1 & 1.2 \\
\hline Collection & 0.4 & 0.7 \\
\hline Threshing & 1.4 & 1.1 \\
\hline Cleaning/Winnowing & 0.5 & 0.4 \\
\hline Drying & 0.1 & 0.2 \\
\hline Packaging & 0.1 & 0.1 \\
\hline Transport & 0.1 & 0.1 \\
\hline Sub-total (i) & 4.7 & 3.9 \\
\hline Farm Level & 0.4 & 0.6 \\
\hline Godown/Cold Storage & 0.1 & 0.03 \\
\hline Wholesale & 0.2 & 0.2 \\
\hline Retail & 0.02 & 0.02 \\
\hline Processing & 0.2 & 0.4 \\
\hline Sub-total (ii) & 0.9 & 1.3 \\
\hline Total Loss (i+ii) & 5.5 & 5.2 \\
\hline
\end{tabular}


Table E3 | Estimates of Loss in Rice

\begin{tabular}{|c|c|c|c|c|c|c|c|c|}
\hline \multirow[b]{2}{*}{ SOURCE } & \multirow[b]{2}{*}{ REGION } & \multicolumn{7}{|c|}{ FARM-LEVEL OPERATIONS } \\
\hline & & HARVESTING & THRESHING & $\begin{array}{l}\text { CLEANING/ } \\
\text { WINNOWING }\end{array}$ & TRANSPORT & HANDLING & STORAGE & $\begin{array}{l}\text { TOTAL } \\
\text { LOSS }\end{array}$ \\
\hline Grover et al. 2012 & Punjab & 1.5 & & & 0.1 & 0.2 & 2.6 & 4.4 \\
\hline Kannan 2014 & Assam & 0.6 & 1.3 & 0.1 & 1.7 & 0.7 & 2.1 & 7.3 \\
\hline Kannan 2014 & Karnataka & 1.9 & 0.2 & 0.1 & 0.6 & 0.3 & 3.8 & 6.8 \\
\hline Kannan 2014 & Punjab & 1.5 & & & 0.1 & 0.2 & & 1.8 \\
\hline Kannan 2014 & Tamil Nadu & 3.1 & 2.1 & 0.2 & 0.6 & & 2.3 & 8.3 \\
\hline Kannan 2014 & Tamil Nadu & 3.2 & 0.8 & & 0.7 & & 0.8 & 5.5 \\
\hline Kannan 2014 & Tamil Nadu & 3.1 & 1.5 & 0.1 & 0.6 & & 1.6 & 6.9 \\
\hline Kannan 2014 & Uttar Pradesh & 2.7 & 1.3 & 0.4 & 0.5 & 0.3 & 0.4 & 5.6 \\
\hline Kannan 2014 & West Bengal & 0.8 & 0.3 & 0.1 & 0.6 & 0.3 & 1.8 & 3.5 \\
\hline
\end{tabular}

Table E4 | Estimates of Loss in Rice, Karnataka

\begin{tabular}{|c|c|c|}
\hline \multicolumn{2}{|l|}{ SOURCE } & BASAVARAJA, H. ET AL 2004 \\
\hline \multirow{8}{*}{ Producer } & Harvesting & 0.4 \\
\hline & Threshing & 0.52 \\
\hline & Cleaning/Winnowing & 0.2 \\
\hline & Drying & 0.8 \\
\hline & Storage & 1.2 \\
\hline & Transport & 0.5 \\
\hline & Packaging & 0.2 \\
\hline & Subtotal (i) & 3.82 \\
\hline \multirow{4}{*}{ Wholesale } & Storage & 0.12 \\
\hline & Transport & 0.17 \\
\hline & Subtotal (ii) & 0.29 \\
\hline & Storage & 0.01 \\
\hline \multirow{3}{*}{ Processing } & Transport & 0.01 \\
\hline & Grain Scattering & 0.01 \\
\hline & Subtotal (iii) & 0.03 \\
\hline \multirow{5}{*}{ Retail } & Storage & 0.53 \\
\hline & Transport & 0.32 \\
\hline & Handling & 0.21 \\
\hline & Subtotal (iv) & 1.06 \\
\hline & Total Loss (i+ii+iii+iv) & 5.19 \\
\hline
\end{tabular}


Table E5 | Estimates of Loss in Rice, All-India

\begin{tabular}{|l|l|l|l|l|l|l|}
\hline SOURCE & THRESHING & $\begin{array}{l}\text { CLEANING/ } \\
\text { WINNOWING }\end{array}$ & $\begin{array}{l}\text { TRANSPORT (FIELD } \\
\text { TO THRESHING } \\
\text { FLOOR) }\end{array}$ & $\begin{array}{l}\text { TRANSPORT } \\
\text { (THRESHING FLOOR } \\
\text { TO STORE) }\end{array}$ & $\begin{array}{l}\text { STORAGE } \\
\text { (FARM-LEVEL } \\
\text { OPERATIONS) }\end{array}$ \\
\hline DMI 2002 & 0.9 & 0.5 & 0.8 & 0.2 & 0.4 \\
\hline
\end{tabular}

Table E6 | Estimates of Loss in Rice, All-India

\begin{tabular}{|c|c|c|c|c|c|}
\hline SOURCE & THRESHING & TRANSPORT & PROCESSING & STORAGE & $\begin{array}{l}\text { TOTAL LOSS (FARM- } \\
\text { LEVEL OPERATIONS) }\end{array}$ \\
\hline Panse Committee 1965 & 2.5 & 0.5 & 2.0 & 6.0 & 11.0 \\
\hline
\end{tabular}

Note: a. CWC: Central Warehousing Corporation; FCl: Food Corporation of India.

b. Yellow highlight indicates the highest loss in the supply chain.

Source: WRI India analysis. 


\section{LIST OF ABBREVIATIONS}

ACZ

AERC

Agro-Climatic Zone

APEDA

Agro-Economic Research Centre

Agricultural and Processed Food Products Export Development Authority

APMC

Agricultural Produce Market Committee

BAIF

Bharatiya Agro Industries Foundation

CCS-IIPA Centre for Consumer Studies-Indian Institute of Public Administration

\begin{tabular}{ll}
\hline CIPHET & $\begin{array}{l}\text { Central Institute of Post Harvest Engineering and } \\
\text { Technology }\end{array}$ \\
\hline CWC & Central Warehousing Corporation \\
\hline
\end{tabular}

DFI Doubling Farmers' Income

DMI Directorate of Marketing and Inspection

\begin{tabular}{ll}
\hline FAO Food and Agriculture Organization of the United \\
Nations
\end{tabular}

FCl Food Corporation of India

FLW Food Loss and Waste

FOLU Food and Land Use Coalition

FSC food supply chain

FSSAI Food Safety and Standards Authority of India

FY financial year

GDP gross domestic product

GHG greenhouse gas

Gol Government of India

\begin{tabular}{ll}
\hline IASR & Indian Agricultural Statistics Research Institute \\
\hline ICAR & Indian Council of Agricultural Research \\
\hline IFSA & Indian Food Sharing Alliance \\
\hline INR & Indian Rupee \\
\hline Mha & million hectares \\
\hline
\end{tabular}

MIDH Mission for Integrated Development of Horticulture

MoAFW Ministry of Agriculture and Farmers Welfare

MoFPI Ministry of Food Processing Industries

\begin{tabular}{|c|c|}
\hline MPUAT & Maharana Pratap Institute of Agriculture and Technology \\
\hline MT/Mt & million metric ton \\
\hline NAAS & National Academy of Agricultural Sciences \\
\hline NABARD & National Bank for Agriculture and Rural Development \\
\hline NCR & National Capital Region \\
\hline NCCD & National Centre for Cold-chain Development \\
\hline NCT & National Capital Territory \\
\hline NGO & nongovernmental organization \\
\hline NWR & Negotiable Warehouse Receipt \\
\hline $\mathrm{OBC}$ & Other Backward Class \\
\hline PEG & Private Entrepreneurs Godown \\
\hline SC & Scheduled Caste \\
\hline SDGs & Sustainable Development Goals \\
\hline SFAC & Small Farmers' Agribusiness Consortium \\
\hline ST & Scheduled Tribe \\
\hline TNAU & Tamil Nadu Agricultural University \\
\hline UJA & Udyen Jain and Associates \\
\hline WRI & World Resources Institute \\
\hline USD & United States Dollar \\
\hline RMC & Regulated Market Committee \\
\hline MSP & Minimum Support Price \\
\hline PAU & Punjab Agricultural University \\
\hline UAS & University of Agricultural Sciences \\
\hline UNEP & United Nations Environment Programme \\
\hline
\end{tabular}




\section{COMMON NAME}

SCIENTIFIC NAME

\begin{tabular}{ll} 
Arecanut & Areca catechu \\
\hline Black Pepper & Piper nigrum \\
\hline Cashew & Anacardium occidentale \\
\hline Cauliflower & Brassica oleracea var, botrytis \\
\hline Chickpea & Cicer arietinum \\
\hline Coriander & Coriandrum sativum \\
\hline Groundnut & Arachis hypogaea \\
\hline Guava & Psidium guajava \\
\hline Mango & Mangifera indica \\
\hline Mushroom & Agaricus bisporus \\
\hline Mustard & Brassica juncea \\
\hline Sapota & Manilkara zapota \\
\hline Sorghum & Sorghum bicolor \\
\hline Soybean & Glycine max \\
\hline Helianthus
\end{tabular}

Wheat

Triticum aestivum

\section{ENDNOTES}

1. Average exchange rate in 2014: 60.9994 INR.

2. These include Save Food, the National Pact against Food Waste in France to fight against food waste, the European Union's Circular Economy Action Plan, Champions 12.3, and so on. (Chaboud and Daviron 2017).

3. Crop and livestock produce including five cereals, four pulses, six oilseeds, eight fruits, eight vegetables, sugarcane, four seed spices, three plantation crops, milk, meat, inland and marine fish, poultry meat, and eggs (Jha et al. 2015).

4. Measures recommended include a higher emphasis on investment in infrastructure for post-harvest management; transportation of agricultural goods; replication of models like National Dairy Development Board (NDDB) for retailing of fruits and vegetables; low-cost storage and value addition technologies; bulk handling for agricultural produce by trains; increase availability of refrigerated vans for carriage of fresh farm produce; introduction of a Post Harvest Technology Wing in Krishi Vigyan Kendra (KVK); increased role of self-help groups (SHGs), NGOs, and the private and public sector in reducing post-harvest losses; and minimizing post-harvest losses as a priority research and technology development area.

5. Average exchange rate in 2020: 74.1397 INR.

6. The Farmers' Produce Trade and Commerce (Promotion and Facilitation) Bill, 2020, allows farmers to sell their harvest outside the notified Agricultural Produce Market Committee (APMC) mandis without paying any state taxes or fees. The Farmers (Empowerment and Protection) Agreement on Price Assurance and Farm Services Bill, 2020, facilitates contract farming and direct marketing. The Essential Commodities (Amendment) Bill, 2020, deregulates the production, storage, movement, and sale of several major foodstuffs, including cereals, pulses, edible oils, and onion, except in the case of extraordinary circumstances (Jebaraj 2020).

7. This policy was not the first attempt to reduce waste at social gatherings. In the wake of famines and Chinese aggression, the Government of India issued a guest control order under the Essential Commodities Act in 1960. Since then, many state governments have issued such measures, including the Assam Guest Control Order, Delhi Guest Control Order, Rajasthan Guest Control Order and Mrityu Bhoj Act, 1960, Mizoram Guest Control Order, and the Jammu \& Kashmir Guest Control Order. Most of these orders have become redundant, however, because they lacked public acceptability (CCS-IIPA 2011).

8. Average exchange rate in 2018: 68.4113 INR.

9. Average exchange rate in 2020: 74.1397 INR.

10. The Food Loss Index pilot tested by the FAO in 2018 includes India as one of the case studies for pilot-testing the tool using the two national surveys led by ICAR with IASRI. ICAR-IASRI have also been involved in field-testing the guidelines to estimate post-harvest losses of horticultural crops, livestock products, and fish and fish products, funded by FAO (ICAR-IASRI 2019).

11. Telephone conversation between the authors and Vikas Rawal, Professor, Centre for Economic Studies and Planning, School of Social Sciences, Jawaharlal Nehru University, New Delhi, on September 18, 2020 (Rawal 2020).

12. The Dalwai Committee on Doubling Farmers' Income (DFI) has recommended a comprehensive study using a harmonized yardstick in all regions of the country (DFI 2017).

13. A multi-stakeholder partnership launched in 2013. For details, visit https://www.flwprotocol.org. 


\section{BIBLIOGRAPHY}

Abraham, M. 2020. "Direct-Selling Helps Indian Farmers Swerve Food Waste under Lockdown." Deutsche Welle, May 27.

Agrawal, V.S., and A. Nag. 2013، "Sustainable Food Waste Prevention Strategies to Achieve Food Security in India." International Journal of Agriculture and Food Science Technology 4 (3): 189-94.

Ahmad, M.S., and M.W. Siddiqui. 2015. "Factors Affecting Postharvest Quality of Fresh Fruits." In Postharvest Quality Assurance of Fruits, 7-32.

Aiyar, S. 2017. "The Sordid Saga of Rs, 92,651 Crore Post-harvest Losses." The New Indian Express, January 22.

Ali, J., A. Sharma, and P. Rani. 2015. "Overview of Grain Drying and Storage Problems in India." International Journal of Engineering Research and General Science 3 (5): 674-78.

Arivazhagan, R., P. Geetha, and R. Parthasarathy. 2012. "Analysis of Sources of Fruit Wastages in Retail Outlets in Chennai, Tamil Nadu, India." International Journal of Trade, Economics and Finance 3 (3): 199-204.

Artiuch, P., and K. Samuel. 2012. Sustainable Approaches to Reducing Food Waste in India. Cambridge: Massachusetts Institute of Technology.

Aschemann-Witzel, J. 2016. "Waste Not, Want Not, Emit Less." Science 352 (6284): 408-09.

ASSOCHAM (The Associated Chambers of Commerce and Industry of India). 2017. Cold Chain Technologies: Transforming Food Supply Chains. Consultant Report. New Delhi: Sathguru Management Consultants.

Aulakh, J., and A. Regmi. 2013. Post-harvest Food Losses EstimationDevelopment of Consistent Methodology. In Selected Poster Prepared for Presentation at the Agricultural \& Applied Economics Association's 2013 AAEA \& CAES Joint Annual Meeting, Washington DC.

Balaji, M., and A. Kaur. 2016. "Modeling the Causes of Food Wastage in Indian Perishable Food Supply Chain." Resources, Conservation and Recycling 114: 153-67.

Bandyopadhyay, J., and G. Dalvi. 2017. "Can Interactive Installations Bring About Behaviour Change? Using Interactive Installation to Change Food Waste Behaviours." In Research into Design for Communities, Volume 2, edited by Amaresh Chakrabarti and Debkumar Chakrabarti, 235-45. Singapore: Springer.

Banerjee, S., A.K. Saini, H. Nigam, and V. Vijay. 2020. "IoT Instrumented Food and Grain Warehouse Traceability System for Farmers." Paper presented at the 2020 International Conference on Artificial Intelligence and Signal Processing (AISP), Amaravati, Andhra Pradesh, January 10-12.

Barik, S. 2020. "'Haladi' Loses Its Flavour amid Pandemic." The Hindu, August 31 .

Basappa, G., J.B. Deshmanya, and B.L. Patil. 2007. "Post-harvest Losses of Maize Crop in Karnataka-An Economic Analysis." Karnataka Journal of Agricultural Sciences 20 (1): 50-52.

Basavaraja, H., S.B. Mahajanashetti, and N.C. Udagatti. 2007. "Economic Analysis of Post-harvest Losses in Food Grains in India: A Case Study of Karnataka." Agriculture Economics Research Review 20: 117-26.
Bharucha, J. 2018. "Tackling the Challenges of Reducing and Managing Food Waste in Mumbai Restaurants." British Food Journal 120 (3): 639-49.

Blakeney, M. 2019. "Drivers of Food Waste." In Food Loss and Food Waste: Causes and Solutions by Michael Blakeney, 69-97. E-book. Edward Elgar Publishing.

Braunbeck, C.M. 2014. "Conservation of Stored Grain Cooling." Paper prepared for the 11th International Working Conference on Stored Product Protection, Chiang Mai, November 24-28.

Cardoen, D., P. Joshi, L. Diels, P.M. Sarma, and D. Pant. 2015. "Agriculture Biomass in India: Part 2. Post-harvest Losses, Cost and Environmental Impacts." Resources, Conservation and Recycling 101: 143-53.

Cattaneo, A., M.V. Sánchez, M. Torero, and R. Vos. 2020. "Reducing Food Loss and Waste: Five Challenges for Policy and Research." Food Policy 96 (October): 1-9.

CCS-IIPA (Centre for Consumer Studies-Indian Institute of Public Administration). 2011. Assessment of Wastage of Food and Ostentatious Behaviour During Social Gathering (Marriages, Parties, Meetings, etc.) in National Capital Region Delhi. New Delhi: CCS-IIPA.

Chaboud, G., and B. Daviron. 2017. "Food Losses and Waste: Navigating the Inconsistencies." Global Food Security 12 (March): 1-7.

Chapke, R.R., V.R. Bhagwat, and J.V. Patil. 2013. Sorghum Cultivation for Value-Added Diversified Products and Sweet Sorghum Perspectives. Hyderabad: Directorate of Sorghum Research.

DAC \& FW (Department of Agriculture Cooperation \& Farmers Welfare). 2018. Operational Guidelines 2018-Agricultural Marketing Infrastructure. New Delhi: DAC \& FW.

Department of Agriculture and Cooperation. 2021. "Horticulture Mission for North East \& Himalayan States (HMNEH)." https://midh.gov.in/tmnehs/ forms/contentpage.aspx?lid=1652.

Department of Agriculture Cooperation \& Farmers Welfare. 2021a. "Mission for Integrated Development of Horticulture (MIDH)." https://midh.gov.in/.

Department of Agriculture Cooperation \& Farmers Welfare. 2021b. "National Horticulture Mission (NHM)." https://hortnet.gov.in/.

Department of Food \& Public Distribution. 2021a. "Private Entrepreneurs Guarantee (PEG) Scheme." https://dfpd.gov.in/pegScheme_C.htm.

Department of Food \& Public Distribution. 2021b. "Construction of Steel Silos." https://dfpd.gov.in/silosScheme_C.htm.

De Steur, H., J. Wesana, M.K. Dora, D. Pearce, and X. Gellynck. 2016. "Applying Value Stream Mapping to Reduce Food Losses and Wastes in Supply Chains: A Systematic Review." Waste Management 58: 359-68.

DFI (Committee for Doubling Farmers' Income). 2017. Post-production Agri-Logistics: Maximising Gains for Farmers. Volume III of Report of the Committee for Doubling Farmers' Income. New Delhi: DFI Committee.

DMI (Directorate of Marketing \& Inspection). 2005. Abstract of Reports on Marketable Surplus and Post-harvest Losses of Foodgrains in India. Nagpur: DMI. 
DMI (Directorate of Marketing \& Inspection). 2002. Estimation of Marketable Surplus \& Post Harvest Losses of Foodgrains in India. Nagpur: DMI.

Dorward, L.J. 2012. "Where Are the Best Opportunities for Reducing Greenhouse Gas Emissions in the Food System (Including the Food Chain)? A Comment." Food Policy 37 (4): 463-66.

Down to Earth. 2019. "Union Budget 2019-20: Income Support for Farmers Drives Historic Allocation for Agri Ministry." July 5.

Dutta, R.A., M. Makwana, and H. Parmar. 2013a. Assessment of Pre and Post Harvest Losses in Soybean Crop in Rajasthan. Anand: Agro-Economic Research Centre (AERC).

Dutta, R.A., M. Makwana, and H. Parmar. 2013b. Assessment of Pre and Post Harvest Losses in Tur Crop in Gujarat. Anand: Agro-Economic Research Centre (AERC).

\section{EAT. 2019. Summary Report of the EAT-Lancet Commission. Stockholm: EAT.}

FA0 (Food and Agricultural Organization of the United Nations). 2011. Global Food Losses and Food Waste-Extent, Causes and Prevention. Rome: FAO.

FA0 (Food and Agricultural Organization of the United Nations). 2018a. Food Loss Analysis: Causes and Solutions-Case Study on the Chickpea Value Chain in the Republic of India. Rome: FAO.

FAO (Food and Agricultural Organization of the United Nations). 2018b. Food Loss Analysis: Causes and Solutions-Case Study on the Mango Value Chain in the Republic of India. Rome: FAO

FA0 (Food and Agricultural Organization of the United Nations). 2018c. Food Loss Analysis: Causes and Solutions-Case Study on the Rice Value Chain in the Republic of India. Rome: FAO.

FA0 (Food and Agricultural Organization of the United Nations). 2019. The State of Food and Agriculture: Moving Forward on Food Loss and Waste Reduction. Rome: FAO.

Flanagan, K, K. Robertson, and C. Hanson. 2019. Reducing Food Loss and Waste. Washington, DC: World Resources Institute.

Food Loss and Waste Protocol (FLW Protocol). 2016. Food Loss and Waste Accounting and Reporting Standard. Washington, DC: FLW Protocol.

FSSAI (Food Safety and Standards Authority of India). n.d. "Food Donating Agencies." https://sharefood.fssai.gov.in/agency-list.html. Accessed on January 29, 2021.

Gadgil, D.S. 2020. "To Create Awareness about Mumbai Roti Bank in Navi Mumbai Region." Studies in Indian Place Names 40 (4): 857-65.

Gajanana, T.M., M. Sudha, and V. Dakshinamoorthy. 2006. "Marketing and Post-harvest Loss Assessment in Sapota." Journal of Horticultural Science $1(1): 71-75$.

Ganesh, U., M. Shankar, S. Banerji, K. Mahadevan, S. Borthakur, C. Thukral, and S. Yadav. 2018. Reducing Post-harvest Losses in India: Key Initiatives and Opportunities, India: Intellecap.

Gardas, B.B., R.D. Raut, and B. Narkhede. 2017. "Modeling Causal Factors of Post-harvesting Losses in Vegetable and Fruit Supply Chain: An Indian Perspective." Renewable and Sustainable Energy Reviews 80: 1355-371.
Gardas, B.B., R.D. Raut, and B. Narkhede. 2018. "Evaluating Critical Causal Factors for Post-harvest Losses (PHL) In the Fruit and Vegetables Supply Chain in India Using the Dematel Approach." Journal of Cleaner Production 199: 47-61.

Gardas, Bhaskar B., R.D. Raut, N. Cheikhrouhou, and B.E. Narkhede. 2018. "A Hybrid Decision Support System for Analyzing Challenges of the Agricultural Supply Chain." Sustainable Production and Consumption 18: 19-32.

Ghosh, P.R., D. Fawcett, S.B. Sharma, and G.E.J. Poinern. 2016. "Progress towards Sustainable Utilisation and Management of Food Wastes in the Global Economy." International Journal of Food Science 2016: 1-22.

Gol (Government of India). 2021a. "National Cooperative Development Corporation." http://www.ncdc.in.

Gol (Government of India). 2021b. "Directorate of Marketing and Inspection." http://www.dmi.govin.

Gol (Government of India), 2021c. "Small Farmer Agri-Business Consortium." http://www.sfacindia.com.

Gol (Government of India). 2021d. "Ministry of Food Processing Industries." http://www.mofpi.nic.in/.

Gol (Government of India), 2021e. "Indian Grain Storage Management \& Research Institute." https://igmri.dfpd.gov.in/igmri/.

Gol (Government of India), 2021f. "Central Warehousing Corporation." http:// cewacor.nic.in.

Gol (Government of India), 2021g. "Warehousing Development and Regulatory Authority." https://wdra.gov.in.

Gol (Government of India), 2021h. "Food Corporation of India." https://fci. govin.

Gol (Government of India). 2021i. "Agricultural \& Processed Food Products Export Development Authority." http://apeda.gov.in/apedawebsite/.

Gokarn, S., and T.S. Kuthambalayan. 2017. "Analysis of Challenges Inhibiting the Reduction of Waste in Food Supply Chain." Journal of Cleaner Production 168: 595-604.

Grover, D.K., J.M. Singh, and P. Singh. 2012. Assessment of Pre and Post Harvest Losses in Wheat and Paddy Crops in Punjab. Ludhiana: AgroEconomic Research Centre (AERC).

Grover, P., and P. Singh. 2014. "An Analytical Study of Effect of Family Income and Size on Per Capita Household Solid Waste Generation in Developing Countries." Review of Arts and Humanities 3 (1): 127-43.

Gurav, A.M. 2015. "Hotel Food Waste Control: A Model Approach." Revelation -The Research Journal of K. B. Hinduja College 14: 10-24.

Hegazy, R. 2016. "Post-harvest Situation and Losses in India." figshare. https://doi.org/10.6084/m9.figshare.3206851.v1.

Hodges, R.J., A.J. Hall, K. Jayaraj, P. Jaiswal, N. Potdar, and B. Yogand. 1999. "Quality Changes in Farm-Stored Sorghum Grain Grown in the Wet or Dry Season in Southern India-A Technical and Social Study." Paper presented at the 19th ASEAN/1st APEC Seminar on Postharvest Technology, Ho Chi Minh City, November 9-12. 
ICAR-IASRI (Indian Council of Agricultural Research-Indian Agricultural Statistics Research Institute). 2019. Annual Report 2018-2019. New Delhi: ICAR-IASRI.

Jebaraj, Priscilla. 2020. "The Hindu Explains-Who Gains and Who Loses from the Farm Bills?" The Hindu, September 27.

Jebaraj, P. 2020. "The Hindu Explains-What Explains India's Poor Rank under the Global Hunger Index, and What Are the Solutions?" The Hindu, October 25

Jha, S.N., R.K. Vishwakarma, T. Ahmad, A. Rai, and A.K. Dixit. 2015. Assessment of Quantitative Harvest and Post-harvest Losses of Major Crops and Commodities in India. Ludhiana: ICAR-CIPHET.

Joardder, M.U.H., and M.H. Masud. 2019. "Causes of Food Waste." In Food Preservation in Developing Countries: Challenges and Solutions by M.U.H. Joardder and M.H. Masud, 27-55. Switzerland: Springer.

Kannan, E. 2014. Assessment of Pre and Post Harvest Losses of Important Crops in India. Bangalore: Institute for Social and Economic Change (ISEC).

Karanth, G.K. 2017. "'Foodscapes' in Bengaluru-Changing Patterns of Family Eating Out and Waste Generation." International Development Policy-Revue internationale de politique de développement [0nline], 8.2. http://journals.openedition.org/poldev/2480; D0l: https://doi.org/10.4000/ poldev.2480.

Kashyap, D., and T. Agarwal. 2019. "Food Loss in India: Water Footprint, Land Footprint and GHG Emissions." Environment, Development and Sustainability, D0I: https://doi.org/10.1007/s10668-019-00325-4.

Kaushik, R, and J. Singhai. 2019. "An Approach for the Development of a Sensing System to Monitor Contamination in Stored Grain." Paper prepared for the 6th International Conference on Signal Processing and Integrated Networks (SPIN), Noida, March 7-8.

Kitinoja, L. 2010. Identification of Appropriate Postharvest Technologies for Improving Market Access and Incomes for Small Horticultural Farmers in Sub-Saharan Africa and South Asia. Virginia: World Food Logistics Organization (WFLO).

Kumar, A. 2014. "Left Out in the Cold: The Case of Potato Cold Stores in West Bengal." The IUP Journal of Supply Chain Management 11 (2): 7-20.

Kumar, D., and P. Kalita. 2017. "Reducing Postharvest Losses During Storage of Grain Crops to Strengthen Food Security in Developing Countries." Foods 6 (1): 8.

Kumar, $P_{1,}$ and D. Kumar. 2018, "Comprehensive Study on Food Waste Management in Hotel and Tourism Industry." International Journal of Enhanced Research in Management \& Computer Applications 7 (1): 366-72.

Kumar, V., S.K. Purbey, and A.K.D. Anal. 2016. "Losses in Litchi at Various Stages of Supply Chain and Changes in Fruit Quality Parameters." Crop Protection 79: 97-104.

Lipinski, B., C. Hanson, J. Lomax, L. Kitinoja, R. Waite, and T. Searchinger. 2013. Reducing Food Loss and Waste. Working Paper. Installment 2 of "Creating a Sustainable Food Future." Washington, DC: World Resources Institute.

Maiti, R., A.K. Thakur, A. Gupta, and D. Mandal. 2018. "Post Harvest Management of Agricultural Produce." In Research Trends in Bioresource
Management and Technology, edited by R. Maiti, H.G. Rodríguez, B. Ghosh, N.C. Sarkar, D. Mandal, R. Meena, A.K. Thakur, and A.V. Ramanjaneyulu, 137-66. Salt Lake City: American Academic Press.

Mehra, B., and A. Joshi. 2016. "Challenges in the Vegetable Supply Chain in Kumaun Region of Uttarakhand, India." Research Journal of Social Science \& Management 6 (3): 131-36.

Menon, V.K. 2020. "Konkan's Alphonso Farmers Brace Up for Severe Losses." Mid-Day, March 29.

MetaMeta، 2017. SMART Technologies for Improved Livelihoods and Environmental Management.

Ministry of Health and Family Welfare. 2019. Food Safety and Standards Authority of India Notification. New Delhi: Government of India.

MoFPI (Ministry of Food Processing Industries). 2021. "Pradhan Mantri Kisan SAMPADA Yojana." https://mofpi.nic.in/Schemes/pradhan-mantrikisan-sampada-yojana.

Munesue, Y., T. Masui, and T. Fushima. 2015. "The Effects of Reducing Food Losses and Food Waste on Global Food Insecurity, Natural Resources, and Greenhouse Gas Emissions." Environmental Economics and Policy Studies 17: 43-77.

Murthy, D.S., T.M. Gajanana, M. Sudha, and V. Dakshinamoorthy. "Marketing and Post-harvest Losses in Fruits: Its Implications on Availability and Economy." Indian Journal of Agricultural Economics. 64 (2).

NAAS (National Academy of Agricultural Sciences). 2019. Saving the Harvest: Reducing the Food Loss and Waste. Policy Brief No. 5. New Delhi: NAAS.

Naik, G., and D.N. Suresh. 2018. "Challenges of Creating Sustainable AgriRetail Supply Chains." IIMB Management Review 30: 270-82.

Naik, S.N., and G. Kaushik. n.d. Grain Storage in India: An Overview. New Delhi: Centre for Rural Development \& Technology, IIT Delhi.

Nanda, S.K., R.K. Vishwakarma, H.V.L. Bathla, A. Rai, and P. Chandra. 2012. Harvest and Post-harvest Losses of Major Crops and Livestock Produce in India. Ludhiana: ICAR.

Naqvi, S.A.M.H. 2004. "Diagnosis and Management of Pre and Post Harvest Diseases of Citrus Fruit." In Diseases of Fruits and Vegetables, Volume 1 by S. A. M. H. Naqvi, 339-59. Netherlands: Kluwer Academic Publishers.

Narayanan, S. 2020. "How India's Agrifood Supply Chains Fared During the Covid-19 Lockdown, from Farm to Fork." Blog. July 20. https://www.ifpri.org/ blog/how-indias-agrifood-supply-chains-fared-during-covid-19-lockdownfarm-fork.

NCCD (National Centre for Cold-Chain Development). 2015. All India ColdChain Infrastructure Capacity (Assessment of Status \& Gap). New Delhi: NCCD.

NHB (National Horticulture Board). 2021. "National Horticulture Board (NHB)." http://nhb.govin/about,aspx?enc=3Z008K5CzcdC/ Yq6HcdlxG0a4CHxzFBZ8EVJjUuGruc=.

Nigam, R, and S. Sharma. 2017. "Food Waste Management." Amity Journal of Energy \& Environment Studies 3 (2): 1-8. 
NITI Aayog. 2019. SDG India: Index \& Dashboard, 2019-20. New Delhi: NITI Aayog.

Pandian, M.A., S. Saranya, R.L. Rathi, G. Kiruthika, and S. Anita. 2019. "Food Waste Management-Survey on Current Trends around Erode, Tamil Nadu." International Research Journal of Multidisciplinary Technovation 1 (6): 387-93.

Parfitt, J., M. Barthel, and S. Macnaughton. 2010. "Food Waste within Food Supply Chains: Quantification and Potential for Change to 2050." Philosophical Transactions of the Royal Society B: Biological Sciences 365: 3065-81.

Parliament, Rajya Sabha. 2001. "Post Harvest Losses of Foodgrains." Monsoon Session (Unstarred Question Number 39). New Delhi.

Parshad, V.R. 1999. "Rodent Control in India." Integrated Pest Management Reviews 4: 97-126.

Pattanaik, B.B., and R.K. Tripathi. 2016. "Grain Storage Research: Handling and Storage of Food Grains in India." Indian Journal of Entomology 78: 17-27.

Pattnaik, K. R. Kumar, and S. Pal. 2020. Internet of Things and Analytics for Agriculture, Volume 2. Singapore: Springer Nature.

Planning Commission. 2012. Report of the Committee on Encouraging Investments in Supply Chains Including Provision for Cold Storages for More Efficient Distribution of Farm Produce. New Delhi: Planning Commission.

Prasad, C.B. Venkata Krishna. 2019. "A Study on Food Loss in Agricultural Supply Chain and Measures to Mitigate with Special Reference to Indian Agricultural Sector." ISBR Management Journal 5 (1).

Ramanathan, A., and R. Parthasarathy. 2014. "Fruit Wastages from Farm Gate to Retail Outlets in Tamil Nadu, India-With Specific Focus on Fruit Processing Units." Middle-East Journal of Scientific Affairs 21 (11): 1994-2003.

Ravi, S.C., and K.B. Umesh. 2018. "Food Loss Foot Print: Implications for Food Security and Environment in India." Paper presented at the 30th International Conference of Agricultural Economists, Vancouver, July 28August 2

Rawal, V., M. Kumar, A. Verma, and J. Pais. 2020. "India Let 65 Lakh Tonnes of Grain Go to Waste in Four Months, Even as the Poor Went Hungry." Scroll, June 3 .

Renganathan, L. 2017. "Safe Management of Paddy to Prevent Post-harvest Losses." The Hindu, June 25.

Roy, R., and D. Chhabra. 2016. "Automation of Grain Storage in India." Journal of Basic and Applied Engineering Research 3 (7): 641-43.

Saadat, A., S. Barman, and L.I. Shukla. 2020. "Reduction of Food Wastage: Roles of Administrative Interventions and Cultural Ecosystem Services." In Zero Hunger, edited by W.L. Filho, A.M. Azul, L. Brandli, P.G. Özuyar, and T. Wall, 1-21. Switzerland: Springer.

Sab, M., M.B. Ashok, and S.N. Sudhakara. 2017. "Estimation of Post-harvest Losses of Mangoes at Different Stages from Harvesting to Consumption." International Journal of Current Microbiology and Applied Sciences 6 (12): $310-18$.

Viña, C.S., R. Singh, and N. Elwell. 2020. "Rural Women Must Be at the Heart of Covid-19 Response and Recovery." Blog. September 21. https://www.wri. org/blog/2020/09/rural-women-must-be-heart-covid-19-response-andrecovery?utm_campaign=wridigest\&utm_source=wridigest-2020-106\&utm_medium=email\&utm_content=readmore.

Sarode, N., and P.H. Wani. 2017. "To Study the Awareness of Food Security and Need of Portion Control in Quick Service Restaurants." International Journal of Multidisciplinary Education and Research 2 (4): 18-25.

Sekar, I. 2012، "Institutions in Indian Agriculture: Imperatives for Innovations." Agricultural Situation in India 69 (7): 379-93.

SFAC (Small Farmers' Agribusiness Consortium). 2012. Value Chain Analysis of Select Crops in North Eastern States. New Delhi: SFAC.

Shanker, K., R. Shankar, and R. Sindhwani. 2019. Advances in Industrial and Production Engineering. Singapore: Springer

Sharma, A., B.K. Singh, and N. Anand. 2016. "Fruit Processing Industry in India: A Short Review." In Cold Chain Logistics in Horticulture \& Agriculture by N. Anand, 1-17. Dehradun, Uttarakhand: Winsar Publishing.

Sharma, H.C., A.S. Alur, C.R. Reddy, K. Jayaraj, V.J. Varaprasad, K.M.V. Reddy, B.V.S. Reddy, and K.N. Rai. 2007. Management of Sorghum and Pearl Millet Pests in Bulk Storage. Global Theme on Crop Improvement. Andhra Pradesh: International Crops Research Institute for the Semi-Arid Tropics (ICRISAT).

Sharon, M. E. Magdalene, C.V.K. Abirami, and K. Alagusundaram. 2014. "Grain Storage Management in India." Journal of Postharvest Technology 2 (1): 12-24.

Shroff, S., S.S. Kalamkar, and J. Kajale. 2011. Impact of Emerging Marketing Channels in Agricultural Marketing in Maharashtra-Benefit to ProducerSellers and Marketing Costs and Margins of Major Agricultural Commodities. Pune: Agro-Economic Research Centre (AERC).

Singh, A. 2020, "Covid and Food Security: Ensuring Zero Hunger-Resilient and Strong Systems Are Needed." Financial Express, July 31.

Singh, D.K., R. Desai, N. Walde, and P.B. Karandikar. "Nano Warehouse: A New Concept for Grain Storage in India." 2014 International Conference on Green Computing Communication and Electrical Engineering (ICGCCEE), Coimbatore, 2014, pp. 1-6, doi: 10.1109/ICGCCEE.2014.6921404.

Singh, K. K. 2014. "Food Losses and Wastage: Scenario of India." In Knowledge and Information for Sustainable Food Systems: A Workshop of the FAO/UNEP Programme on Sustainable Food Systems, edited by A. Meybeck, and S. Redfern, 127-31. Rome: FAO,

Singh, S.P., B.K. Sikka, and A. Singh. 2009. "Supply Chain Management and Indian Fresh Produce Supply: Opportunities and Challenges." Paper presented at the International Food \& Agribusiness Management Association, 19th Annual World Symposium, Budapest, June 20-23.

Singleton, G. 2003. Impacts of Rodents on Rice Production in Asia. Laguna: International Rice Research Institute.

Sushma, M. 2018. "Now There's A Way to Offset Food Wasted at Weddings." DownToEarth, December 12.

Sushma, M. 2020. "COVID-19: Food Wastage on the Rise." DownToEarth, April 2.

The Economic Times. 2020. "Government Sets Foodgrain Production Target at Record at 298.3 Mn Tonnes for 2020-21 Crop Year." April 16. 
The Hindu. 2020. "Third Tranche of Economic Package-FM Announces Plan for ₹1 Lakh Crore Farm Infrastructure Fund." May 15.

Thi, N.B. Dung, G. Kumar, and C.Y. Lin. 2015. "An Overview of Food Waste Management in Developing Countries: Current Status and Future Perspective." Journal of Environmental Management 157: 220-29.

UJA (Udyen Jain and Associates). 2019. Indian Cold Chain Logistic Sector. India: UJA.

Upadhyay, R.K., and S. Ahmad. 2011. "Management Strategies for Control of Stored Grain Insect Pests in Farmer Stores and Public Ware Houses." World Journal of Agricultural Sciences 7 (5): 527-49.

Vikas, M., D. Bansal, and M. Sharma. 2017. "Reduction and Management of Waste in Hotel Industries." International Journal of Engineering Research and Application 7 (7): 34-37.

Grebmer, K.V., J. Bernstein, R. Alders, O. Dar, R. Kock, F. Rampa, M. Wiemers, K. Acheampong, A. Hanano, B. Higgins, R.N. Chéilleachair, C. Foley, S. Gitter, K. Ekstrom, and H. Fritschel. 2020.2020 Global Hunger Index: One Decade to Zero Hunger: Linking Health and Sustainable Food Systems. Bonn: Welthungerhilfe; and Dublin: Concern Worldwide.

Xue, L., and G. Liu. 2019. "Introduction to Global Food Losses and Food Waste." In Saving Food: Production, Supply Chain, Food Waste and Food Consumption, edited by C.M. Galanakis, 1-31. London: Academic Press.

Xue, L., G. Liu, J. Parfitt, X. Liu, E. V. Herpen, Å. Stenmarck, C. O'Connor, K. Östergren, and S. Cheng. 2017. "Missing Food, Missing Data? A Critical Review of Global Food Losses and Food Waste Data." Environmental Science \& Technology 51 (12): 6618-33. 


\section{ACKNOWLEDGMENTS}

The authors would like to thank Aruna Rangachar (IFHD), Geeta Sethi (World Bank), Nitya Chibber (CRB), Nutan Kaushik (Amity Institute of Horticulture Studies \& Research), and S. Vijay Kumar (FOLU India) for their insightful reviews of the publication, and we are grateful for their time. We are also thankful to colleagues at WRI, Arivudai Nambi Appadurai, Craig Hanson, Esben Larsen, Liz Goodwin, Lanvin Concessao, and Norbert Henninger, for their critical inputs to the publication, and we are thankful for their support

The authors acknowledge the contribution of the Technical Working Group members Ashis Mondal (Action for Social Advancement), Hukum Chandra (Indian Council of Agricultural Research-Indian Agricultural Statistics Research Institute), Pradnya Paithankar (World Food Programme), Rajeshree Joshi (Bharatiya Agro Industries Foundation Development Research Foundation), and Vikas Rawal (Jawaharlal Nehru University) for their guidance and support for the research and publication.

The authors are thankful to Fiona Hinchcliffe for the editorial support. We are also grateful to the Research and Data Innovation team at WRI. We would like to thank Akanksha Mhatre and Garima Jain for design support.

For this publication, WRI India and FOLU India platform gratefully acknowledge the financial support of Norway's International Climate and Forests Initiative (NICFI).

\section{ABOUT THE AUTHORS}

Monika Agarwal is a Senior Manager with the Sustainable Landscapes and Restoration Program at WRI India.

Sushant Agarwal is a former Senior Project Associate with the Sustainable Landscapes and Restoration Program at WRI India.

Subia Ahmad is a former Consultant with the Sustainable Landscapes and Restoration Program at WRI India.

Ruchika Singh is the Director of the Sustainable Landscapes and Restoration Program at WRI India.

K.M. Jayahari is the FOLU India Country Coordinator based at WRI India.

\section{ABOUT WRI INDIA}

WRI India is a research organization that turns big ideas into action at the nexus of environment, economic opportunity, and human well-being.

\section{Our Challenge}

Natural resources are at the foundation of economic opportunity and human well-being. But today, we are depleting Earth's resources at rates that are not sustainable, endangering economies and people's lives. People depend on clean water, fertile land, healthy forests, and a stable climate. Livable cities and clean energy are essential for a sustainable planet. We must address these urgent, global challenges this decade.

\section{Our Vision}

We envision an equitable and prosperous planet driven by the wise management of natural resources. We aspire to create a world where the actions of government, business, and communities combine to eliminate poverty and sustain the natural environment for all people.

\section{Our Approach}

COUNT IT

We start with data. We conduct independent research and draw on the latest technology to develop new insights and recommendations. Our rigorous analysis identifies risks, unveils opportunities, and informs smart strategies. We focus our efforts on influential and emerging economies where the future of sustainability will be determined.

\section{CHANGE IT}

We use our research to influence government policies, business strategies, and civil society action. We test projects with communities, companies, and government agencies to build a strong evidence base. Then, we work with partners to deliver change on the ground that alleviates poverty and strengthens society. We hold ourselves accountable to ensure that our outcomes will be bold and enduring.

\section{SCALE IT}

We don't think small. Once tested, we work with partners to adopt and expand our efforts regionally and globally. We engage with decisionmakers to carry out our ideas and elevate our impact. We measure success through government and business actions that improve people's lives and sustain a healthy environment.

\section{ABOUT FOLU}

The Food and Land Use Coalition (FOLU) India platform is a joint initiative between the Council on Energy, Environment and Water (CEEW), the Indian Institute of Management, Ahmedabad (IIM-A), The Energy and Resources Institute (TERI), Revitalising Rainfed Agriculture Network (RRAN) and World Resources Institute India (WRI India). The FOLU India platform works toward developing long-term pathways for sustainable food and land use systems to help inform policy decisions in the country and beyond. 